DOE/ER/60292-7

\title{
OPERATION AND RESEARCH AT THE ITHACA MAP3S REGIONAL PRECIPITATION CHEMISTRY SITE
}

\author{
FINAL REPORT \\ Thomas J. Butler and Gene E. Likens \\ Institute of Ecosystem Studies \\ The New York Botanical Garden \\ Mary Flagler Cary Arboretum \\ Millbrook, New York 12545
}

\section{NOTICE}

This report was prepared as an account of work sponsored by the United States Government. Neither the United States nor the Department of Energy, nor any of their employees, nor any of their contractors, subcontractors, or their employees, make any warranty, express or implied, or assumes any legal liability or responsibility for the accuracy, completeness, or usefulness of any information, apparatus, produce or process disclosed or represents that its use would not infringe privately-owned rights.

\author{
JULY 1991 \\ Prepared For:
}

U. S. DEPARTMENT OF ENERGY AGREEMENT NO. DE-FG02-85ER60292 MASTER 


\section{Abstract}

Annual precipitation chemistry data from network start-up through 1988 is presented for the nine MAP3S sites. Time trends show significant negative linear regressions $(\mathrm{P}<0.10)$ for $\mathrm{SO}_{4}=$ at 2 sites, $\mathrm{H}^{+}$at 4 sites, $\mathrm{Ca}^{++}$at 1 site, and $\mathrm{Na}^{+}$at 1 site. Significant positive regressions over time include: $\mathrm{NH}_{4}{ }^{+}$at 2 sites, $\mathrm{Ca}^{++}$at 1 site, $\mathrm{K}^{+}$at 4 sites, and $\mathrm{Cl}^{-}$at 2 sites. The Ithaca site shows the highest number of significant trends, with positive trends for $\mathrm{Cl}^{-}$, $\mathrm{NH}_{4}{ }^{+}, \mathrm{Ca}^{++}$, and $\mathrm{K}^{+}$, and a negative trend for $\mathrm{H}^{+}$.

Linear regressions of annual $\mathrm{SO}_{4}=$ concentrations on $\mathrm{SO} 2$ emissions show a significant positive relationship for Whiteface, Illinois, and Ohio at $\mathrm{p}<0.10,0.02$, and 0.05 respectively. Overall for all MAP3S sites. plus Hubbard Brook a $25 \%$ decline in SO2 emissions over the region has been accompanied by a $16.5 \%$ decline in annual precipitation concentrations of $\mathrm{SO}_{4}=$. Linear regressions of $\mathrm{H}^{+}$concentrations on combined emissions of $\mathrm{SO} 2$ plus NOx show significant positive relationships for Whiteface, Ithaca, Illinois, Ohio, and Lewes at $p<0.10,0.02,0.05,0.05$, and 0.10 respectively. For the region as a whole, a $20 \%$ decline in combined emissions has been accompanied to a $20 \%$ decline in $\mathrm{H}^{+}$ concentrations. Thus a linear relationship exists between combined emissions and precipitation $\mathrm{H}^{+}$concentrations.

No strong relationship exists for NOx emissions and precipitation $\mathrm{NO}^{-}$concentration at the annual, seasonal or monthly level. Removing the NOx transportation sector, removing high and low precipitation values, or high $\mathrm{pH}$ values also does little to improve the $\mathrm{NOx}-\mathrm{NO}_{3}^{-}$concentration relationships. Dry deposition components such as $\mathrm{PAN}, \mathrm{NO} 2$, gaseous $\mathrm{HNO}_{3}$, or aerosol $\mathrm{NO}_{3}^{-}$should be includedin the future with precipitation $\mathrm{NO}_{3}{ }^{-}$to relate emissions of NOx to nitrogen deposition.

The appreciable MAP3S data record, which is of high quality, should continue, especially to monitor and investigate changes in precipitation chemistry which will result from changing emission levels proposed by 1990 Amendments to the Clean Air Act. 


\section{Introduction}

The Ithaca MAP3S Regional Precipitation Chemistry Site has been in continuous operation since September of 1976. Site operation during the entire time period has been performed by Tom Butler. Event and daily (as of 3/89) precipitation samples are collected and analyzed for field $\mathrm{pH}$, lab $\mathrm{pH}$, conductivity, $\mathrm{SO}_{4}=$, dissolved $\mathrm{SO}_{2}, \mathrm{NO}_{3}^{-}, \mathrm{Cl}^{-}, \mathrm{H}^{+}, \mathrm{NH}_{4}^{+}, \mathrm{Ca}^{++}, \mathrm{Mg}^{++}, \mathrm{K}^{+}$, and $\mathrm{Na}^{+}$. Complementary meteorological and air chemistry data are being collected (as of 8/87) at a co-located National Dry Deposition Network (NDDN) site. Precipitation chemistry samples are still being collected and analyzed although funding by DOE for monitoring and analysis was discontinued in November 1990. Because DOE support for the Ithaca MAP3S site was removed suddenly and without adequate warning, the last few months of operation of the site and preparation of this final report were supported by funds provided to the Institute of Ecosystem Studies by the General Reinsurance Corporation. This support is gratefully acknowledged.

Precipitation chemistry research has been a fundamental part of network operations since it's inception. Personnel associated with the Ithaca site, Gene E. Likens and Tom J. Butler, continue to pursue the objective of research associated with the MAP3S program. Published research papers associated with the Ithaca MAP3S project are listed in Appendix A.

\section{The MAP3S Network Record - Annual Data}

\section{Precipitation}

Yearly precipitation values through 1988 for the nine MAP3S sites are displayed in Fig. 1. Mean annual precipitation and annual standard deviations for the sites are presented in Table 1. Average precipitation for all sites is $100.45 \mathrm{~cm} / \mathrm{yr}$ with a range of $85.0 \mathrm{~cm} / \mathrm{yr}$ for Illinois to $111.0 \mathrm{~cm}$ for Oak Ridge . 


\section{Ionic Concentrations and Time Trends}

Figs. 2 through 10 are plots for all sites of the annual precipitation-weighted means for $\mathrm{SO}_{4}=, \mathrm{NO}_{3}{ }^{-}, \mathrm{Cl}^{-}, \mathrm{H}^{+}, \mathrm{NH}_{4}^{+}, \mathrm{Ca}^{++}$, $\mathrm{Mg}^{++}, \mathrm{K}^{+}$, and $\mathrm{Na}^{+}$, through 1988 . Linear regression analysis of a particular ion regressed on year was performed on each set of graphs. Significant regressions at a level of $\mathrm{p}<0.10$ are indicated by a regression line. Whiteface and Illinois show significant downward trends in $\mathrm{SO}_{4}=$ (Fig. 2) and Whiteface, Ithaca, Virginia, and Illinois all show significant downward trends in $\mathrm{H}^{+}$(Fig. 3) over time. $\mathrm{NO}_{3}^{-}$(Fig. 4), shows no significant trend for the period of record. Further discussion concerning these ions and how they relate to emissions of $\mathrm{NOx}$ and $\mathrm{SO} 2$ will be presented below.

$\mathrm{NH}_{4}{ }^{+}$demonstrates a significant positive time trend for Ithaca and Virginia (Fig. 5). Ithaca and Illinois show a significant positive and negative trend, respectively, for $\mathrm{Ca}^{++}$(Fig. 6). No significant relationships exist for $\mathrm{Mg}^{++}$(Fig. 7). Four of the nine sites, Ithaca, Penn State, Virginia and Oak Ridge, show a significant positive time trend for $\mathrm{K}^{+}$(Fig. 8). $\mathrm{Na}^{+}$has a significant downward time trend at Oak Ridge (Fig. 9), and $\mathrm{Cl}^{-}$shows a positive time trend for both Ithaca and Penn State (Fig. 10). Overall the Ithaca site shows the highest number of significant trends among the MAP3S stations. A significant negative trend exists for $\mathrm{H}^{+}$, and positive trends exist for $\mathrm{Cl}^{-}, \mathrm{NH}_{4}^{+}, \mathrm{Ca}^{++}$, and $\mathrm{K}^{+}$at the Ithaca site. Continuing the MAP3S network precipitation chemistry record for several more years would be necessary to further establish real trends, if they exist, for various ions in precipitation for the eastern U.S.

The relationship between regional $\mathrm{SO} 2$ and NOx emissions on precipitation chemistry

Control of acid inputs to ecosystems is a national and international concern. A major question dealing with this concern is how will reductions in emissions of $\mathrm{SO}_{2}$ and/or NOx affect precipitation chemistry and deposition of acid species. We have addressed this issue in Butler and Likens, 1991, using the MAP3S 
data record from the ADS Precipitation Chemistry Database (Watson and Olsen, 1984) to 1987, plus the Hubbard Brook, N.H. precipitation chemistry record from 1975 to 1987. The analysis excludes the two coastal sites, Brookhaven and Lewes, and also Oak Ridge because of its relatively short record. Emissions data are from Kohout et al. (1990), which is the most current and detailed U.S. emissions record available to us.

Combining data for all seven sites (Whiteface, Ithaca, Penn State, Virginia, Ohio, Illinois and Hubbard Brook) and regressing precipitation chemistry data on emissions, a $22 \%$ decline in $\mathrm{SO} 2$ emissions during the period of record was accompanied by a $16 \%$ $\pm 3 \%$ decline in $\mathrm{SO}_{4}=$ concentration for the Eastern U.S. An $18 \%$ decline in combined emissions of SO2 plus NOx has led to an $18 \% \pm$ $3 \%$ decline in $\mathrm{H}^{+}$concentration. For $\mathrm{NO}_{3}^{-}$regressed on $\mathrm{NOx}$ emissions no significant relationship was found. We have redone this analysis using a data record extending to 1988, and also including the three remaining MAP3S sites (Brookhaven, Lewes, and Oak Ridge). This analysis is presented below.

\section{Annual Emissions}

The trends in annual emissions of SO2 and NOx (from Kohout et al., 1990) are presented in Figs. 11 and 12 respectively. Details on the establishment of source regions for particular sites are given in Butler and Likens (1991). It should be noted that while the magnitude of emissions is different for the various source regions, the trends or patterns in emissions for both $\mathrm{SO} 2$ and NOx are very similar between the various source regions. It is the trend in the emissions that is the most relevant parameter for the regression analyses.

For SO2, peak emissions occured in 1976 or 1977 , and the lowest emissions occurred in 1987 . A $23 \%-27 \%$ decline in $\mathrm{SO} 2$ emissions occurred during this period for the various source regions. Peak NOx emissions occurred in 1977 and 1978 with lowest emission rates in 1987 and 1988, representing a $16 \%$ to $18 \%$ decline in NOx emissions. 


\section{Effects of changing $\mathrm{SO} 2$ emissions on $\mathrm{SO}_{4}=$ concentrations}

Individual regressions for each site of annual precipitation $\mathrm{SO}_{4}=$ concentrations on annual $\mathrm{SO} 2$ emissions from the appropriate source regions are presented in Fig. 13. Whiteface, Illinois and Ohio all show significant positive relationships at $\mathrm{p}<$ $0.10,0.02$ and 0.05 respectively. The remaining six sites show positive relationships, however they are not significant at a level of $\mathrm{p}<0.10$.

If the data for each site were standardized by plotting both emissions and $\mathrm{SO}_{4}=$ concentrations as \%'s of the long-term mean for each site, then the data from all sites (including Hubbard Brook) can be analyzed for the entire region as a whole. This relation is shown in Fig. 14 (a). It is interesting to note that the slope of this regression is a measure of the efficiency with which changing $\mathrm{SO} 2$ emission levels led to changes in $\mathrm{SO}_{4}=$ concentration (and deposition) for the eastern U.S. as a whole. In this analysis the slope is 0.66 which means that for a $25 \%$ decline in SO2 emissions there has been about a $16.5 \%$ decline in precipitation $\mathrm{SO}_{4}=$ concentrations for the MAP3S region as a whole. This $66 \%$ efficiency compares with a $74 \% \pm 15 \%$ (standard error) found in Butler and Likens (1991) where the data record was through 1987 and Brookhaven, Lewes, and Oak Ridge were not included.

The regression line in Fig. 14 (a), while highly significant $(\mathrm{p}<$ 0.01 ) only accounts for $17 \%$ of the variability in the data. This clearly shows that other factors such as oxidants $\left(\mathrm{OH}, \mathrm{H}_{2} \mathrm{O}_{2}\right)$, catalysts, and most likely meteorological factors also control the transformation of $\mathrm{SO}_{2}$ to $\mathrm{SO}_{4}=$. However, this analysis supports the premise that reductions in $\mathrm{SO} 2$ emissions will bring declines in precipitation $\mathrm{SO}_{4}=$ and will reduce acid loading to ecosystems.

\section{Effects of changing NOx plus $\mathrm{SO} 2$ emissions on $\mathrm{H}^{+}$concentrations}

Individual regressions for each site of annual $\mathrm{H}^{+}$concentrations regressed on combined annual emissions of $\mathrm{NOx}$ plus $\mathrm{SO}_{2}$ are presented in Fig. 15. Moles of NOx were added to two times the moles of $\mathrm{SO}_{2}$ to get combined $\mathrm{NOx}$ plus $\mathrm{SO}_{2}$ emission values. One 
mole of NOx has the potential to produce one mole of $\mathrm{H}^{+}$, while one mole of $\mathrm{SO}_{2}$ has the potential to produce 2 moles of $\mathrm{H}^{+}$. Whiteface, Ithaca, Illinois, Ohio, and Lewes show significant positive relationships at $\mathrm{p}<0.10,0.02,0.05,0.05$, and 0.10 respectively. The remaining 4 sites show positive relationships but they are not statistically significant at a level of $p<0.10$.

Fig. 14 (b) is the overall emissions vs $\mathrm{H}^{+}$regression using the same approach as was done for the overall $\mathrm{SO}_{2}-\mathrm{SO}_{4}=$ analysis. The slope, which again is the efficiency with which changing emissions of NOx plus $\mathrm{SO} 2$ lead to changes in $\mathrm{H}^{+}$concentration, is 0.99 or an efficiency of $99 \%$. A $20 \%$ decline in combined emissions has been accompanied by a $20 \%$ decline in precipitation $\mathrm{H}^{+}$ concentration for the region as a whole. This compares well to a slope of $100 \% \pm 15 \%$ for this regression through 1987 and not including Brookhaven, Lewes, and Oak Ridge (Butler and Likens, 1991). Thus, there appears to be a strictly linear relationship for combined NOx plus $\mathrm{SO} 2$ emissions and precipitation $\mathrm{H}^{+}$. This analysis offers strong support for reduced emissions of both NOx and SO2 in order to decrease acid loading to ecosystems.

\section{Effects of changing NOx emissions on precipitation $\mathrm{NO}_{3}$}

In Butler and Likens (1991) no sites showed statistically significant relationships between annual $\mathrm{NOx}$ emissions and $\mathrm{NO}_{3}^{-}$ concentrations in precipitation. In this analysis, updated to 1988 and including Brookhaven, Lewes and Oak Ridge, the results are essentially the same. Fig. 16 shows no significant regressions for all nine MAP3S sites for annual emission and concentration values.

\section{Disaggregation of the $\mathrm{NOx}$ and $\mathrm{NO}^{-}$data}

Seasonal and monthly analysis for NOx and precipitation $\mathrm{NQ}_{3}^{-}$

The lack of significant relationships between annual NOx emissions and annual precipitation $\mathrm{NO}^{-}$at any of the sites raised the question of whether there might be any significant 
relationships at a more disaggregated level of analysis. We therefore performed regressions at selected sites at seasonal and monthly levels. Figs. 17 to 21 are the seasonal regressions for Whiteface, Ithaca, Illinois, Ohio, and also Hubbard Brook. Illinois shows significant NOx $-\mathrm{NO}_{3}^{-}$relationships for the winter $(\mathrm{p}<$ $0.05)$ and fall $(\mathrm{p}<0.10)$ data sets, and Ohio shows a significant relationship for fall $(p<0.02)$. The remaining 17 regressions are not significant at $p<0.10$. Figs. 22 and 23 are the results of a further analysis performed on monthly values for Hubbard Brook, which had the longest record (1975-1988) of the sites examined in this study. Only data for the month of July showed a significant regression $(p<0.02)$.

Removing monthly data where precipitation amounts were more than 1 standard deviation from the average resulted in only one month (October) having a significant relationship $(p<0.05)$ for Hubbard Brook. Also removing monthly data with $\mathrm{pH}$ values greater than 4.5 again left only October with a significant relationship $(p<0.05)$ for Hubbard Brook.

\section{NOx Sector Emissions}

Fig. 24 shows NOx Emissions from 1975 to 1988 by sector for the Northeastern and Southeastern U.S., from Kohout et al., (1990). Northeastern and Southeastern regions are defined in Fig. 25. The two dominant sources of NOx emissions are transportation and electric utilities. Note that the transportation sector shows a decline from the late 1970's to 1988, while electric utilities show an upward trend. Electric utilities which was formally the second major source of NOx emissions is now about equal to transportation, which was formally the major NOx source. These two NOx sources are emitted to the atmosphere in fundamentally different ways. Transportation is a ground level source which may be less susceptable to long range transport and transformation. Electric utility NOx sources, like $\mathrm{SO} 2$ sources from the same sector, are usually emitted from tall stacks and so have a greater potential for long-range transport and transformation.

Because of these basically different modes of emission (see Discussion below) it seemed reasonable to examine the relationship of NOx, without the ground-level transportation 
sector, to $\mathrm{NO}_{3}^{-}$in precipitation. Figs. 26 and 27 are annual regression plots for Whiteface, Ithaca, Penn State, Virginia, Ohio, Lewes, Oak Ridge, and Hubbard Brook. Whiteface and Ohio show significant positive regressions at a level of $P<0.10$ and 0.05 respectively. Lewes shows a significant regression at $\mathrm{p}<0.05$ when the year 1979 is removed from the data set. That particular year recieves a poor rating for the quality of the $\mathrm{NO}_{3}^{-}$data at Lewes, in the ADS database for precipitation chemistry. Previously, Fig. 16 had showed no significant regressions for annual $\mathrm{NO}_{3}^{-}$regressed on $\mathrm{NOx}$ emissions.

Fifty-one $\mathrm{NOx}-\mathrm{NO}_{3}^{-}$regressions have been presented in figures for this report. Only 8 regressions or $i \leqslant \%$ of the total are significant at a level of $\mathrm{p}<0.10$ or less. After examining the NOx $\mathrm{NO}_{3}{ }^{-}$relationship at the annual, seasonal and monthly level, and also stratifying the data to remove low and high precipitation periods and high $\mathrm{pH}$ periods, and finally separating out the transportation sector, we conclude that with the record presently available no strong relationship is discernable between NOx emissions and precipitation $\mathrm{NO}_{3}^{-}$, for the eastern U.S. as a whole.

\section{Discussion}

Other researchers have also had difficulties in establishing significant relationships for $\mathrm{NOx}$ and precipitation $\mathrm{NO}_{3}^{-}$. Rodhe and Rood (1986) found no significant relationships for NOx emissions and $\mathrm{NO}_{3}^{-}$in precipitation for northern Europe. Dillon et al. (1988) found no change in concentration or deposition of precipitation $\mathrm{NO}_{3}{ }^{-}$from 1976 to 1985 , a period when NOx emssions declined 10\%. Hilst and Chapman (1990), using a spatial approach, found a strong to moderate relationship when comparing regional spring and summer $\mathrm{NO}_{3}^{-}$concentration levels to spring and summer NOx emissions for regions in southeastern Canada and the northeastern U.S. However the relationship breaks down in the fall and winter.

There may be a good explanation why a clear NOx precipitation $\mathrm{NO}_{3}{ }^{-}$relationship does not emerge from this study. 
NOx transformation chemistry is dependent on concentrations of other chemical parameters such as $\mathrm{O}_{3}, \mathrm{H}_{2} \mathrm{O}_{2}, \mathrm{OH}$ radical and reactive hydrocarbons and u.v. radiation intensity (Moussiopoulos, 1990). More importantly, precipitation $\mathrm{NO}_{3}{ }^{-}$is only one of several end products for NOx . NO + NO2 atmospheric chemistry can lead to dry deposition of $\mathrm{NOx}, \mathrm{HNO}_{3}$, peroxyacetyl nitrate (PAN) (Olsen et al., 1990), or aerosol nitrate (ie $\mathrm{NH}_{4} \mathrm{NO}_{3}$ (Lindberg et al., 1990; Khwaja and Husain, 1990) and large aerosol $\mathrm{NaNO}_{3}$ or $\mathrm{Ca}\left(\mathrm{NO}_{3}\right)_{2}$ which effectively sediment out (Dasch and Cadle, 1990)). Lindberg et al. (1990) found dry deposition to forested landscapes to account for $60 \%$ and $66 \%$ of the total $\mathrm{NO}_{3}{ }^{-}$ deposition in the southeastern U.S. (Oak Ridge, TN) and Germany respectively. Olsen et al., (1990) in a nitrogen budget for eastern Canada found only $1 / 3$ of the nitrogen deposition as precipitation $\mathrm{NO}_{3}{ }^{-}$, the remaining $2 / 3$ consisting of dry-deposited $\mathrm{NO}_{3}^{-}, \mathrm{NO}_{2}$, and PAN. These data suggest that the addition of the nitrogen dry deposition component to precipitation nitrate values may be critical to establishing a strong relationship between NOx emissions and their end products.

NOx emission types are also a factor. For example NOx dry deposition is a function of surface concentrations. Thus NOx dry deposition losses are much greater for ground level emissions from the transportation sector rather than for elevated sources, such as electric utilities (Simpson et al., 1990). Such ground level emissions, which represent the largest source of NOx emissions, do not allow the regional-scale mixing and long-range transport that occurs in the case of $\mathrm{SO} 2$ emissions. As shown earlier, an attempt was made to remove the transportation sector, which may contribute very little to the formation of precipitation $\mathrm{NO}_{3}{ }^{-}$, from the NOx emissions. However removing this sector results in a change in NOx emissions of less than $12 \%$ for the Northeastern U.S. over the period of record. Such a small change is not conducive to regression analysis.

The establishment of the NDDN network, begun in 1987, will hopefully allow the incorporation of the dry deposition component into an analysis of nitrogen deposition as a function of NOx emissions. At present the NDDN record (quarterly data) extends to 1990 (E. Edgerton, pers. comm.), but the MAP3S record in the ADS database extends only to 1988 and must therefore be 
updated to at least 1990 . When this is accomplished then we can begin to look at the relationship between NOx emissions and how they relate to wet and dry nitrogen chemistry and deposition.

\section{Addendum}

The MAP3S precipitation chemistry network is the longest operating U.S. network, and the only network collecting precipitation chemistry samples on a daily basis in the United States. The high quality of the data record is also a critically important aspect of the MAP3S network. At a time when declining emission levels are mandated by the 1990 Amendments to the Clean Air Act we believe that it is critical that this particular precipitation chemistry record be continued to monitor any changing rainfall chemistry parameters, and to investigate the probable causes of such changes. 


\section{REFERENCES}

Butler T. J. and Likens G. E. (1991) The impact of changing regional emissions on precipitation chemistry in the eastern United States. Atmos. Environ. 25A (2), 305-315.

Dasch J. M. and Cadle S. H. (1990) The removal of nitric acid to atmospheric particles during a wintertime field study. Atmos. Environ. 24A (10), 2557-2562.

Dillon P. J., Lusis M., Reid R., and Yap D. (1988) Ten-year trends in sulphate, nitrate and hydrogen deposition in central Ontario. Atmos. Environ. 22 (5), 901-905.

Hilst G. R. and Chapman E. G. (1990) Source-receptor relationships for wet $\mathrm{SO}_{4}=$ and $\mathrm{NO}_{3}^{-}$production. Atmos. Environ. $24 \mathrm{~A}(7), \quad 1889-1901$.

Khwaja H. A. and Husain L. (1990) Chemical characterization of acid precipitation in Albany, New York. Atmos. Environ. 24A(7), 1869-1882.

Kohout E. J., Miller D. J., Nieves L. A., Rothman D. S., Saricks C. L., Stodolsky F., and Hanson D. A. (1990) Current emission trends for nitrogen oxides, sulfur dioxide, and volatile organic compounds by month and state: methodology and results. ANL/EAIS/TM-25 Argonne National Laboratory, Argonne, Illinois. 426 pp.

Lindberg S. E., Bredemeier M., Schaefer D. A., and Qi L. (1990) Atmospheric concentrations and deposition of nitrogen and major ions in conifer forests in the United States and Federal Republic of Germany. Atmos. Environ. 24A(8), 2207-2220.

Moussiopoulos N. (1990) Influence of power plant emissions and industrial emissions on the leeward ozone levels. Atmos. Environ. $24 \mathrm{~A}(6), \quad 1451-1460$.

Olsen M. P., Bottenheim J. W., and Oikawa K. K. (1990) Nitrogen budget for eastern Canada. Atmos. Environ. 24A(4), 897-901. 
Rhode H. and Rood M. J. (1986) Temporal evolution of nitrogen compounds in Swedish precipitation since 1955. Nature 321, 762764.

Simpson D., Perrin D. A., Varey J. E., and Williams M. L. (1990) Dispersion modelling of nitrogen oxides in the United Kingdom. 24A, 1713-1733.

Watson C. R. and Olsen A. R. (1984) Acid Deposition System (ADS) for statistical reporting: system design and users code manual. PNL-4826, Pacific Northwest Laboratory, Richland, Washington. 
Table 1. Average annual precipitation and standard deviation for the MAP3S sites. $n=$ number of years of record to 1988. See Fig. 1 for data on individual years.

\begin{tabular}{lccc}
\hline Site & $\mathrm{n}$ & $\begin{array}{c}\text { Mean Precipitation } \\
(\mathrm{cm})\end{array}$ & $\begin{array}{c}\text { Standard Deviation } \\
(\mathrm{cm})\end{array}$ \\
\hline Whiteface & 12 & 101.5 & 15.1 \\
Ithaca & 12 & 101.5 & 14.0 \\
Penn State & 12 & 98.2 & 17.4 \\
Virginia & 12 & 101.1 & 24.2 \\
Illinois & 11 & 85.5 & 14.4 \\
Ohio & 10 & 92.4 & 12.0 \\
Brookhaven & 11 & 108.5 & 22.0 \\
Lewes & 11 & 104.9 & 21.3 \\
Oak Ridge & 8 & 111.0 & 19.0 \\
\hline
\end{tabular}




\section{LIST OF FIGURES}

Fig. 1 Annual Precipitation Amounts for the MAP3S sites.

Fig. 2 Annual volume-weighted $\mathrm{SO}_{4}=$ concentrations for the MAP3S sites. Linear regressions with a significant slope at $\mathrm{p}<$ 0.10 are illustrated with a slope line and a stated level of significance.

Fig. 3 Annual volume-weighted $\mathrm{H}^{+}$concentrations for the MAP3S sites. Linear regressions with a significant slope at $p<0.10$ are illustrated with a slope line and a stated level of significance.

Fig. 4 Annual volume-weighted $\mathrm{NO}_{3}{ }^{-}$concentrations for the MAP3S sites. No linear regressions are significant at $\mathrm{p}<0.10$.

Fig. 5 Annual volume-weighted $\mathrm{NH}_{4}{ }^{+}$concentrations for the MAP3S sites. Linear regressions with a significant slope at $\mathrm{p}<$ 0.10 are illustrated with a slope line and a stated level of significance.

Fig. 6 Annual volume-weighted $\mathrm{Ca}^{++}$concentrations for the MAP3S sites. Linear regressions with a significant slope at $\mathrm{p}<$ 0.10 are illustrated with a slope line and a stated level of significance.

Fig. 7 Annual volume-weighted $\mathrm{Mg}^{++}$concentrations for the MAP3S sites. No linear regressions are significant at $\mathrm{p}<0.10$.

Fig. 8 Annual volume-weighted $\mathrm{K}^{+}$concentrations for the MAP3S sites. Linear regressions with a significant slope at $p<0.10$ are illustrated with a slope line and a stated level of significance.

Fig. 9 Annual volume-weighted $\mathrm{Na}^{+}$concentrations for the MAP3S sites. Linear regressions with a significant slope at $p<0.10$ are illustrated with a slope line and a stated level of significance. 
Fig. 10 Annual volume-weighted $\mathrm{Cl}^{-}$concentrations for the MAP3S sites. Regressions with a significant slope at $p<0.10$ are illustrated with a slope line and a stated level of significance.

Fig. 11 Annual SO2 emissions from source regions for Whiteface, Ithaca, and Brookhaven (WF,IT,BH); Penn State, Virginia, Lewes, and Oak Ridge (PS,VA,LE,OR); Illinois and Ohio (IL,OH); and for the eastern $2 / 3$ of the U.S. Source regions represent the same states as found in Butler and Likens (1991).

Fig. 12 Annual NOx emissions from source regions for Whiteface, Ithaca, and Brookhaven (WF,IT,BH); Penn State, Virginia, Lewes, and Oak Ridge (PS,VA,LE,OR); Illinois and Ohio (IL,OH); and for the eastern $2 / 3$ of the U.S. Source regions represent the same states as found in Butler and Likens (1991).

Fig. 13 Annual precipitation $\mathrm{SO}_{4}=$ concentrations regressed on annual SO2 emissions. Regressions with a significant slope at $\mathrm{p}<$ 0.10 are illustrated with a slope line and a stated level of significance.

Fig. 14 Linear regressions of annual volume-weighted $\mathrm{SO}_{4}=$ (a) and $\mathrm{H}^{+}$(b) concentrations in precipitation for all MAP3S sites plus Hubbard Brook (expressed as the \% of each site mean) on annual emissions for each appropriate source region (expressed as the \% of the appropriate source region mean for each site). The slope of the regression line $(X 100)$ is a conservative estimate of the efficiency of how changing emission levels affect changing levels of $\mathrm{SO}_{4}=$ and $\mathrm{H}^{+}$concentration over the entire study region. The slope is 0.66 for (a) and 0.99 for (b).

Fig. 15 Annual precipitation $\mathrm{H}^{+}$concentrations regressed on annual SO2 plus NOx emissions (2 times moles SO2, plus moles NOx). Regressions with a significant slope at $p<0.10$ are illustrated with a slope line and a stated level of significance. 
Fig. 16 Annual precipitation $\mathrm{NO}_{3}^{-}$concentrations regressed on annual NOx emissions. No linear regressions are significant at $\mathrm{p}<$ 0.10 .

Fig. 17 Seasonal precipitaton $\mathrm{NO}_{3}{ }^{-}$concentrations at Whiteface regressed on seasonal NOx emissions. No linear regressions are significant at $\mathrm{p}<0.10$.

Fig. 18 Seasonal precipitaton $\mathrm{NO}_{3}^{-}$concentrations at Ithaca regressed on seasonal NOx emissions. No linear regressions are significant at $\mathrm{p}<0.10$.

Fig. 19 Seasonal precipitaton $\mathrm{NO}_{3}^{-}$concentrations at Illinois regressed on seasonal NOx emissions. Linear regressions with a significant slope at $\mathrm{p}<0.10$ are illustrated with a slope line and a stated level of significance.

Fig. 20 Seasonal precipitaton $\mathrm{NO}_{3}^{-}$concentrations at Ohio regressed on seasonal NOx emissions. Linear regressions with a significant slope at $\mathrm{p}<0.10$ are illustrated with a slope line and a stated level of significance.

Fig. 21 Seasonal precipitaton $\mathrm{NO}_{3}^{-}$concentrations at Hubbard Brook regressed on seasonal NOx emissions. Linear regressions with a significant slope at $\mathrm{p}<0.10$ are illustrated with a slope line and a stated level of significance.

Fig. 22 Monthly precipitaton $\mathrm{NO}_{3}^{-}$concentrations at Hubbard Brook regressed on monthly NOx emissions,' January through June. No linear regressions are significant at $\mathrm{p}<0.10$. 
Fig. 23 Monthly precipitaton $\mathrm{NO}_{3}{ }^{-}$concentrations at Hubbard Brook regressed on monthly NOx emissions, July through December. Linear regressions with a significant slope at $p<0.10$ are illustrated with a slope line and a stated level of significance.

Fig. 24 Northeast (a) and Southeast (b) sectoral emissions trends showing seasonal variations, 1975 to 1988 (from Kohout et al.,1990).

Fig. 25 Defined regions for Fig. 24.

Fig. 26 and 27 Annual precipitation $\mathrm{NO}_{3}^{-}$concentrations regressed on annual NOx emissions, not including the transportation sector. Linear regressions with a significant slope at $\mathrm{p}<0.10$ are illustrated with a slope line and a stated level of significance. 


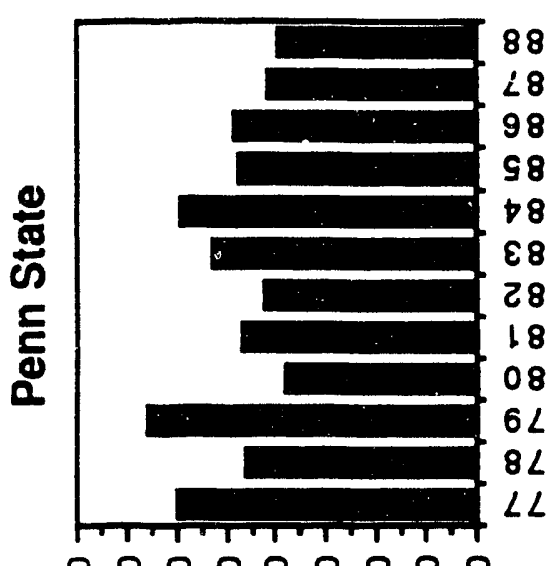

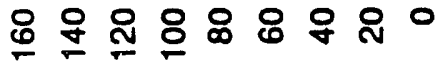

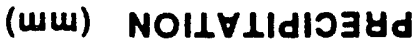

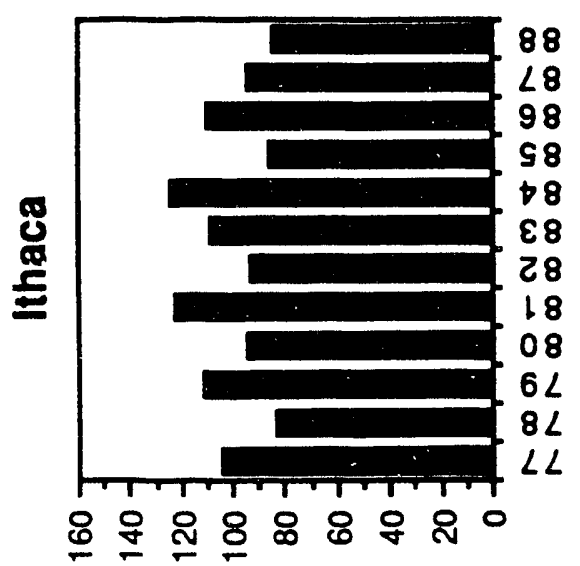

(um) Nol1VLldiogyd

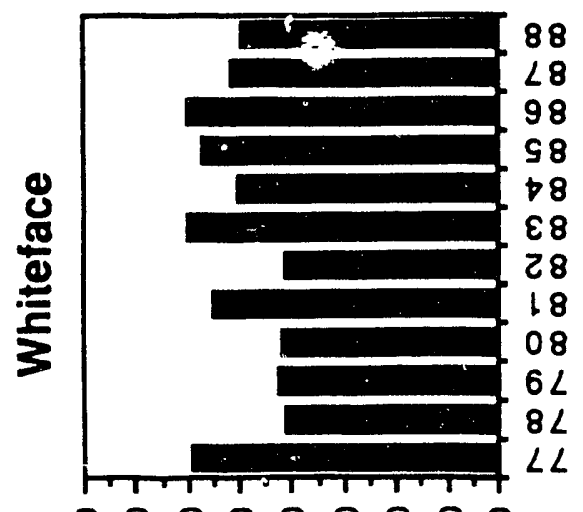

원 옹요. 웅 웅

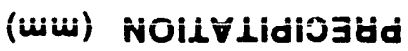

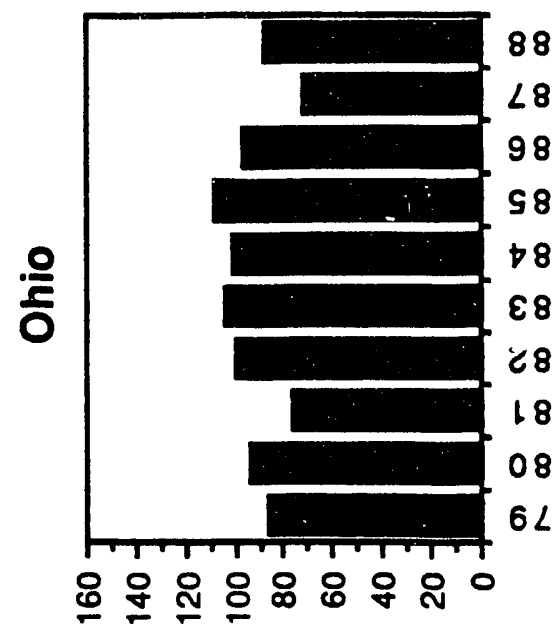

(uw) NOILVIIdIJ
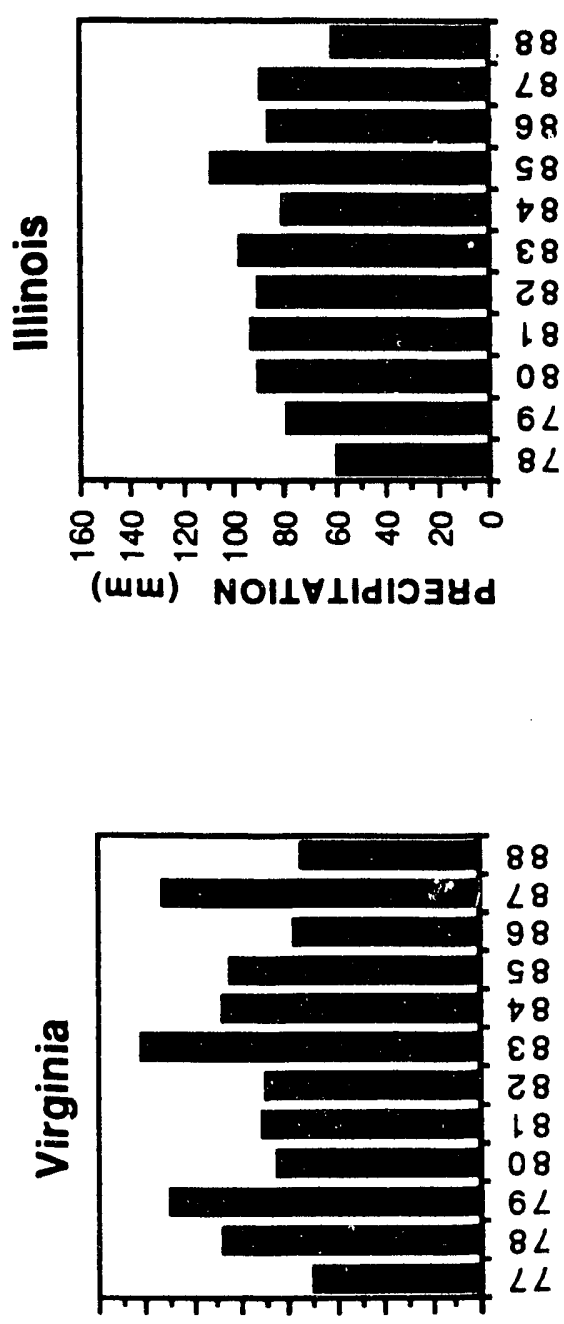

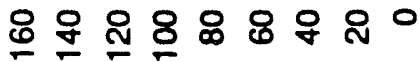

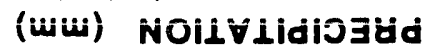

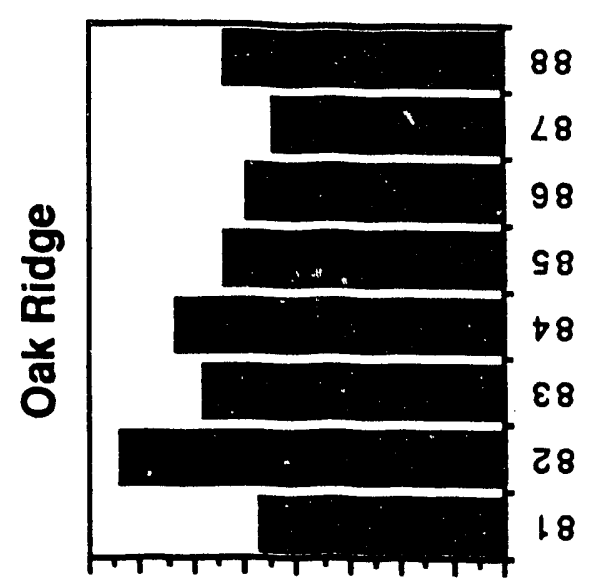

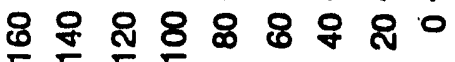

(wu) NOIL 1 IdIOتצd

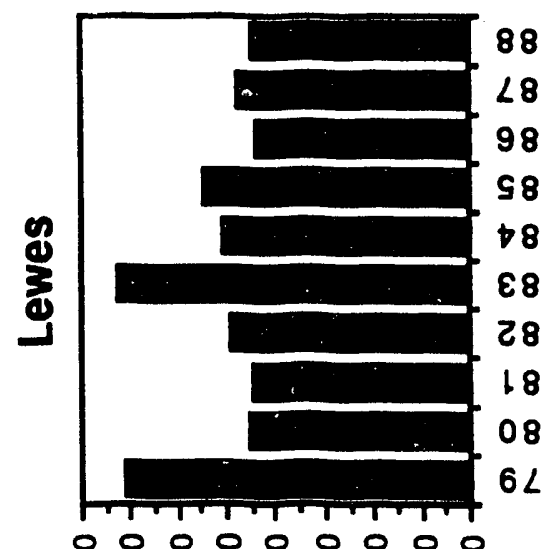

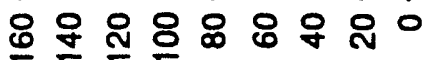

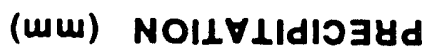

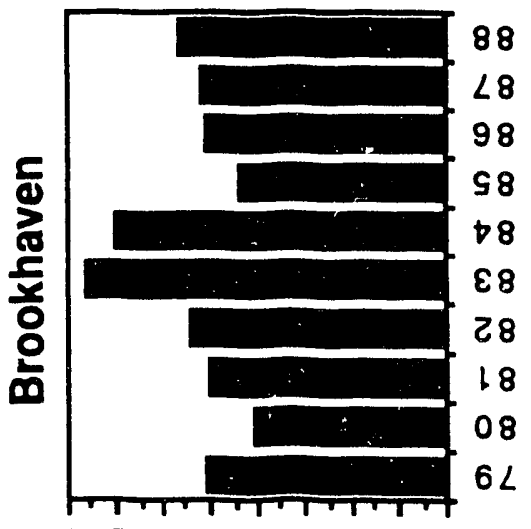

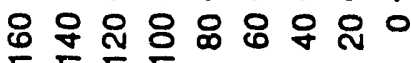
(uw) NoIL 11 dis 

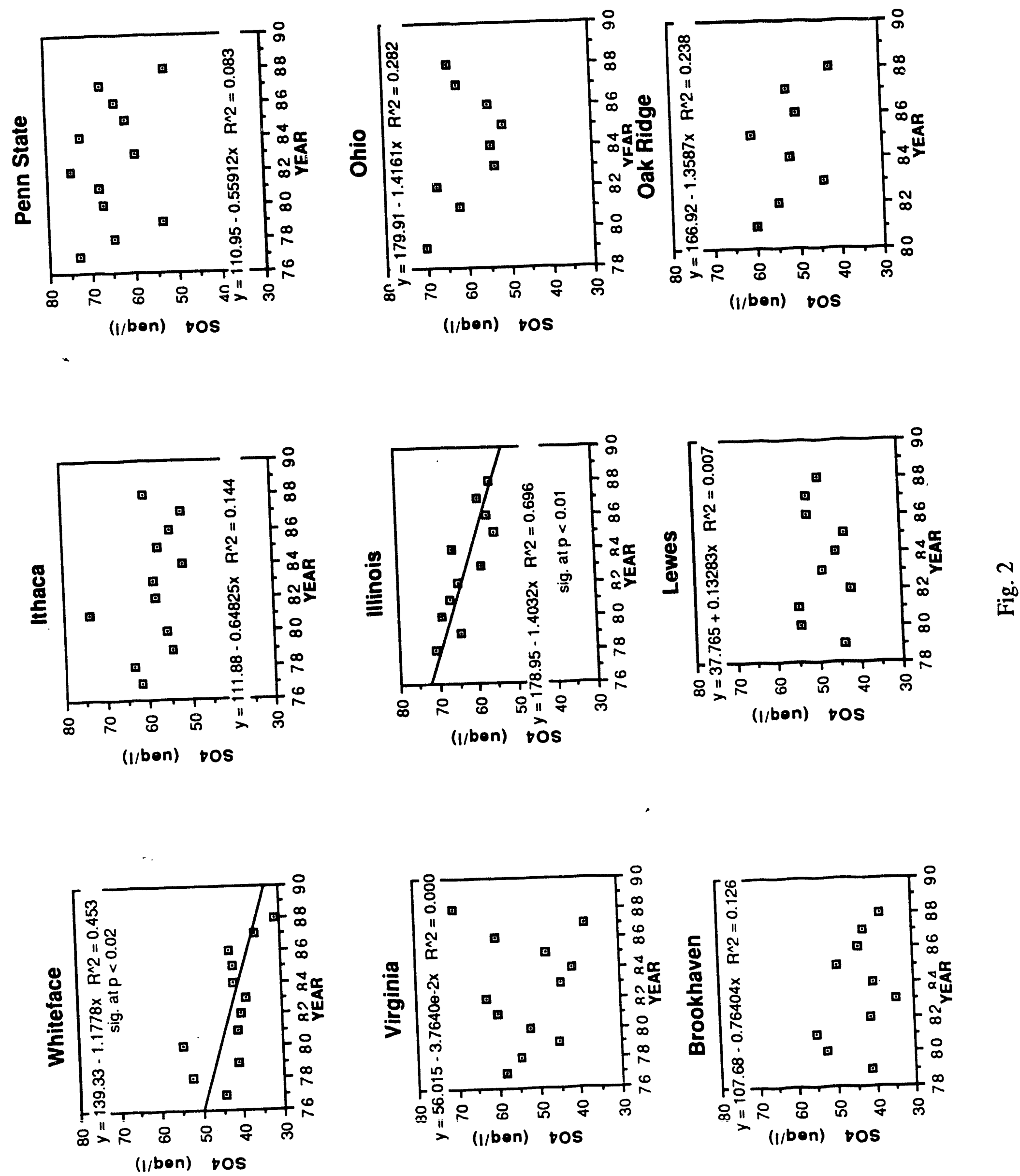

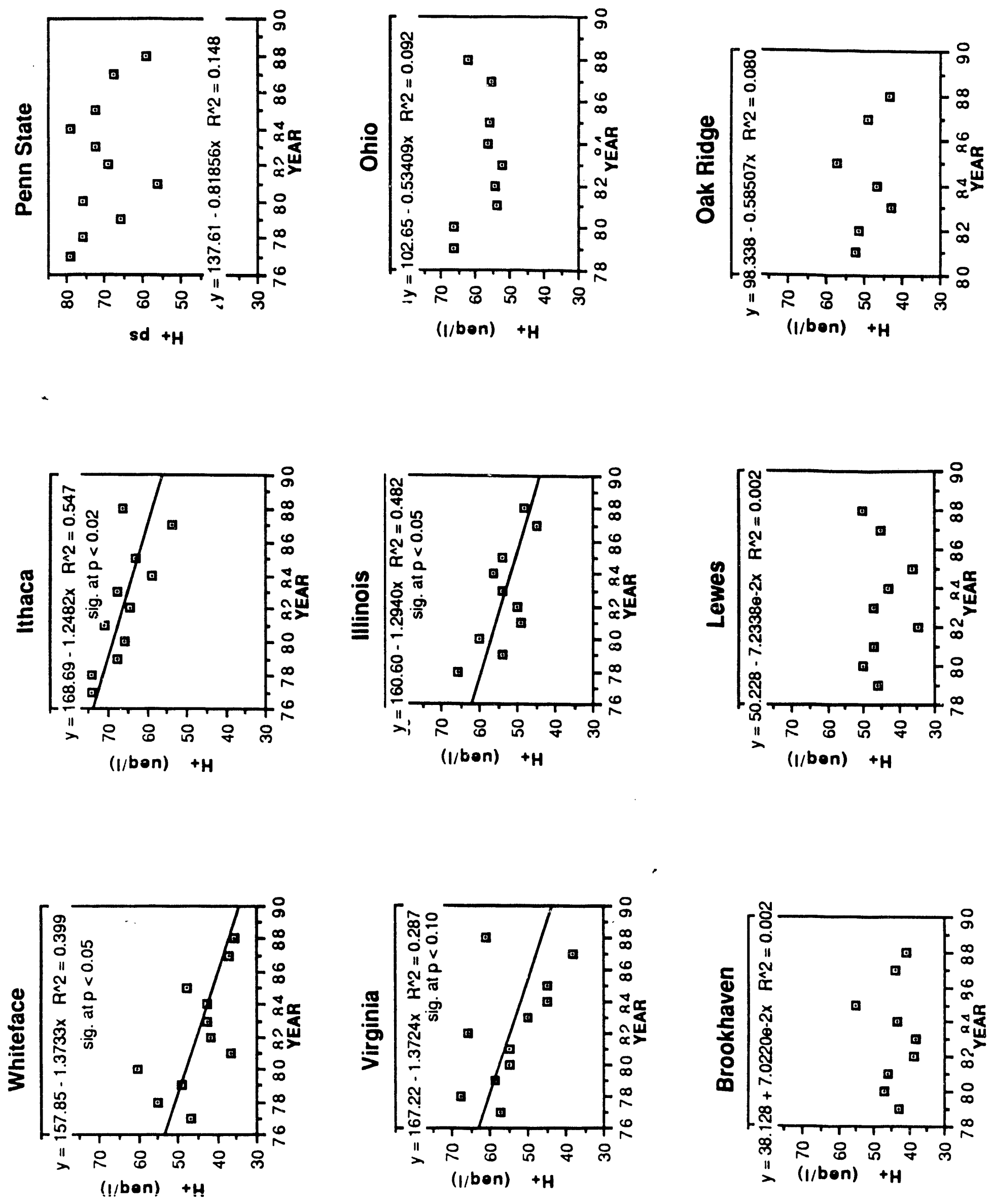

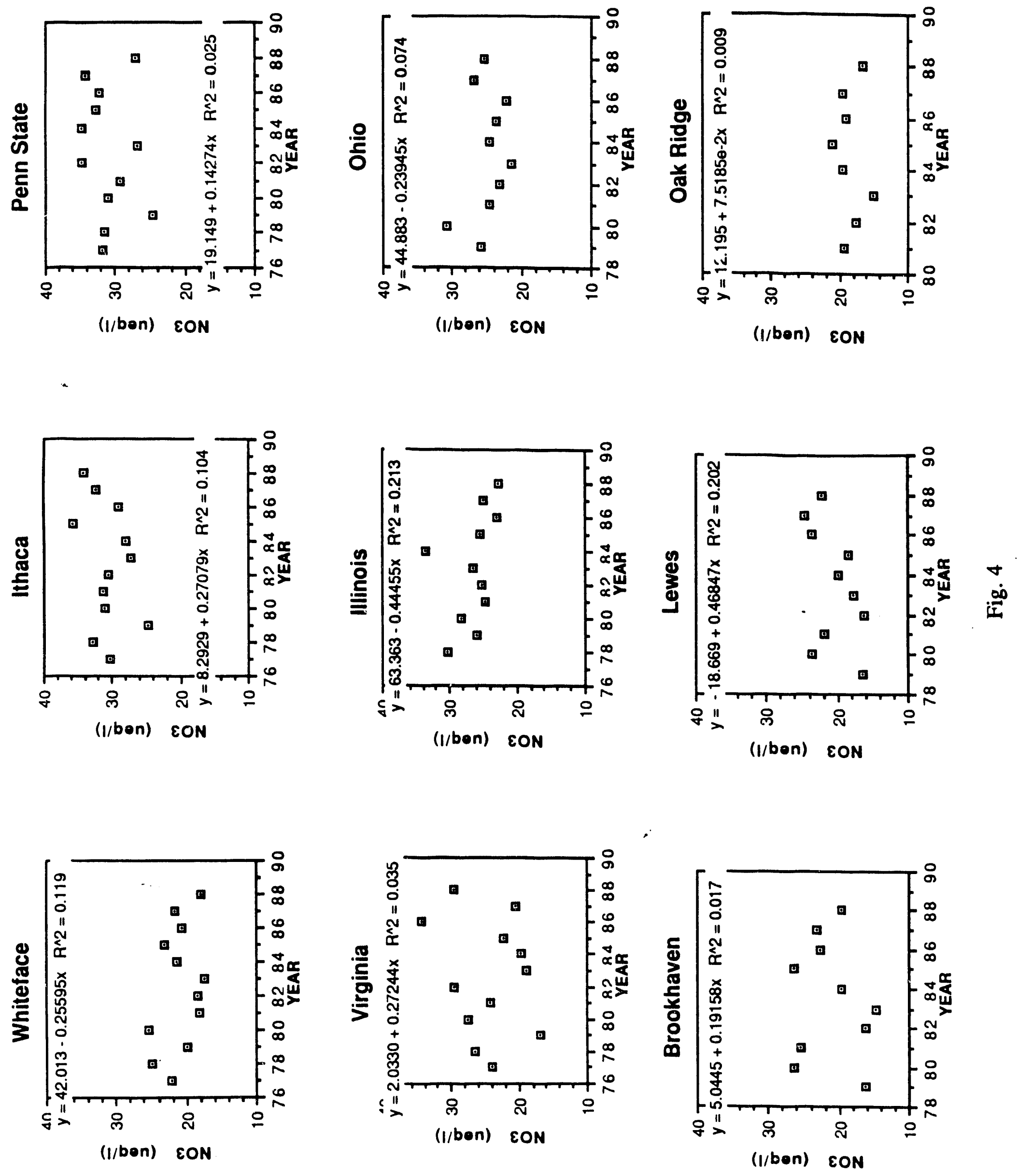


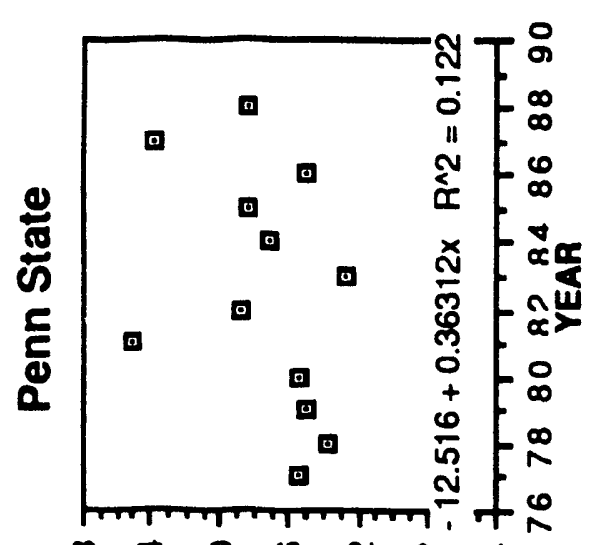

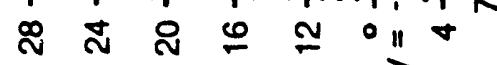
(1/bon) BHN
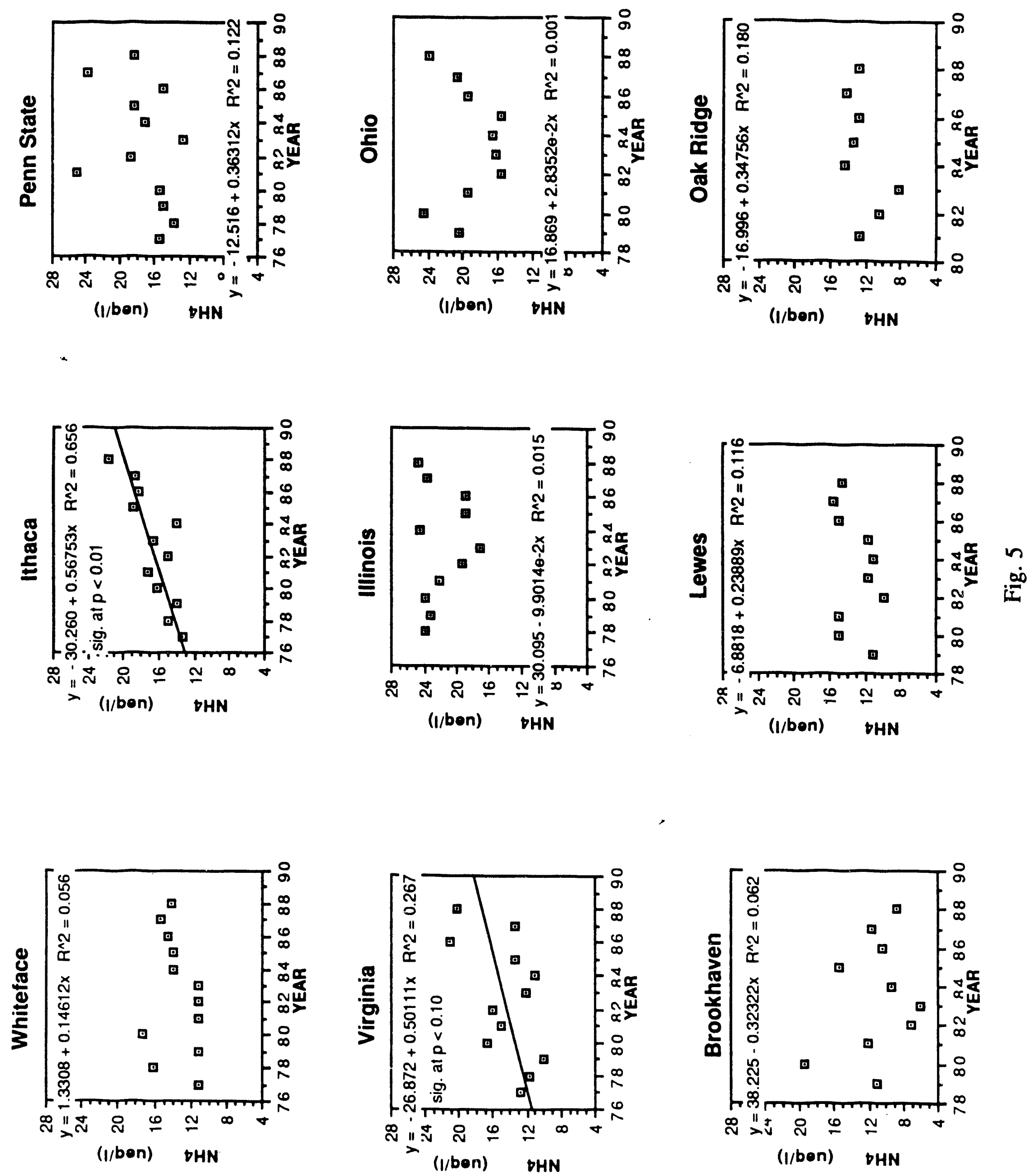

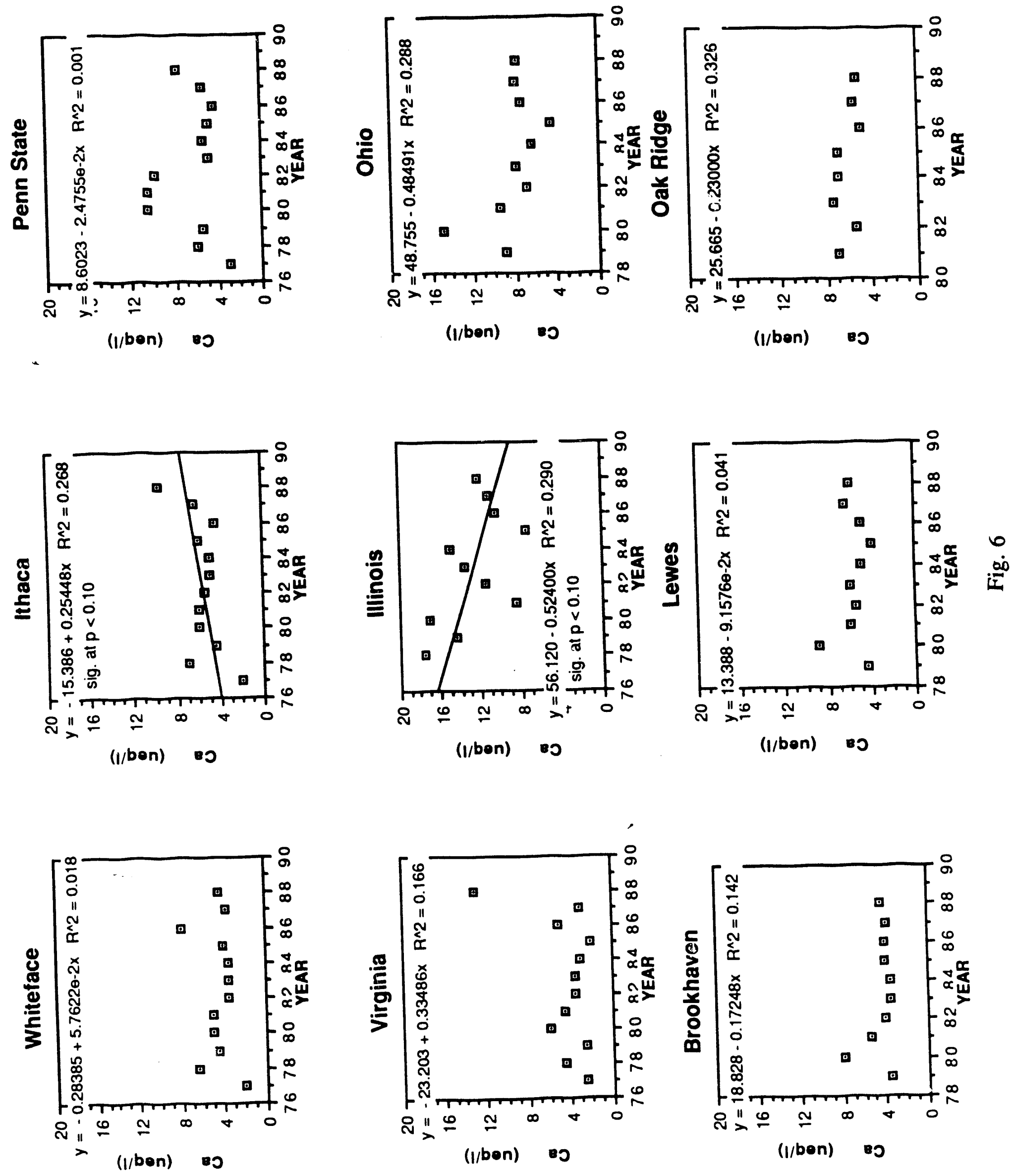

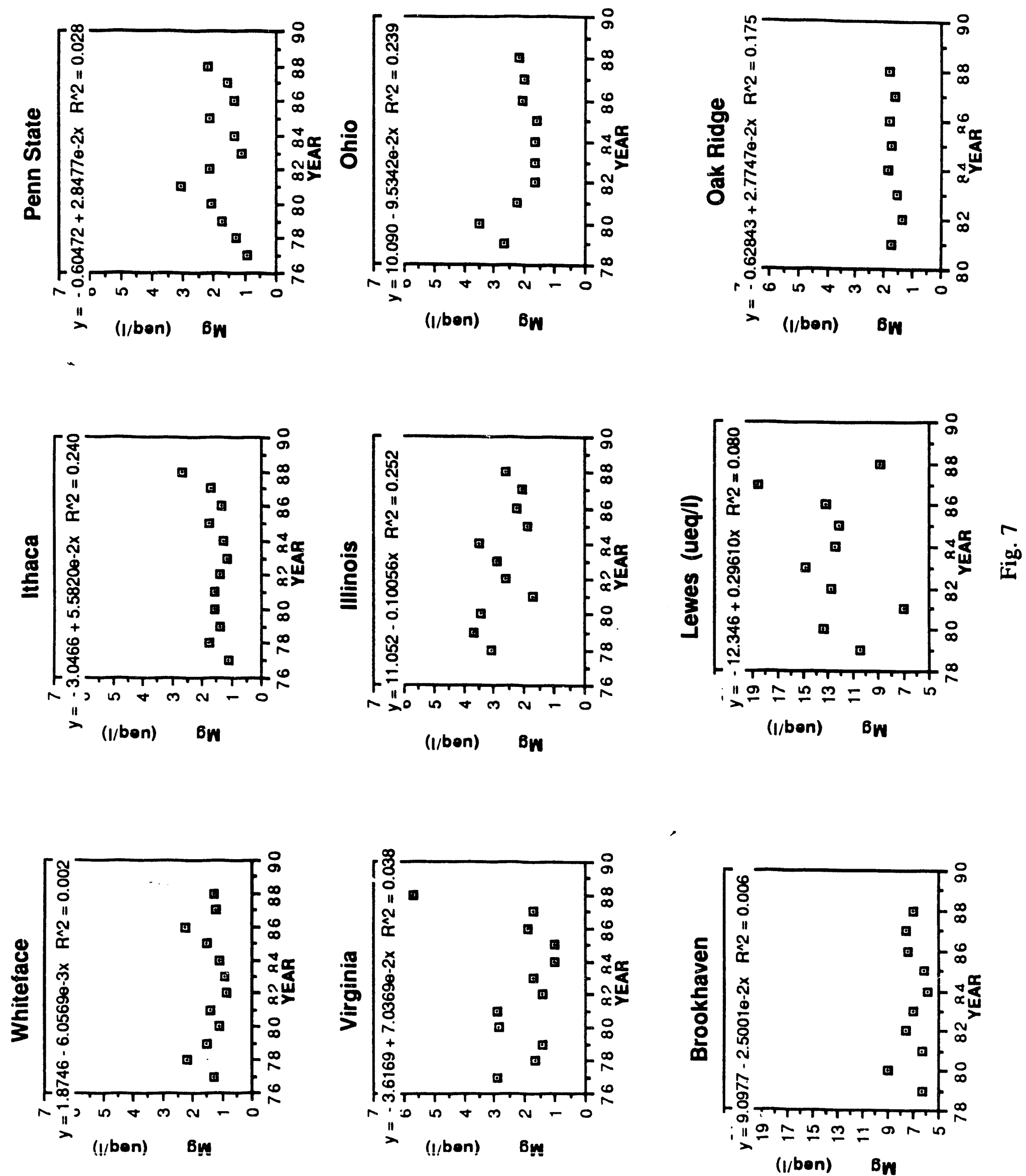

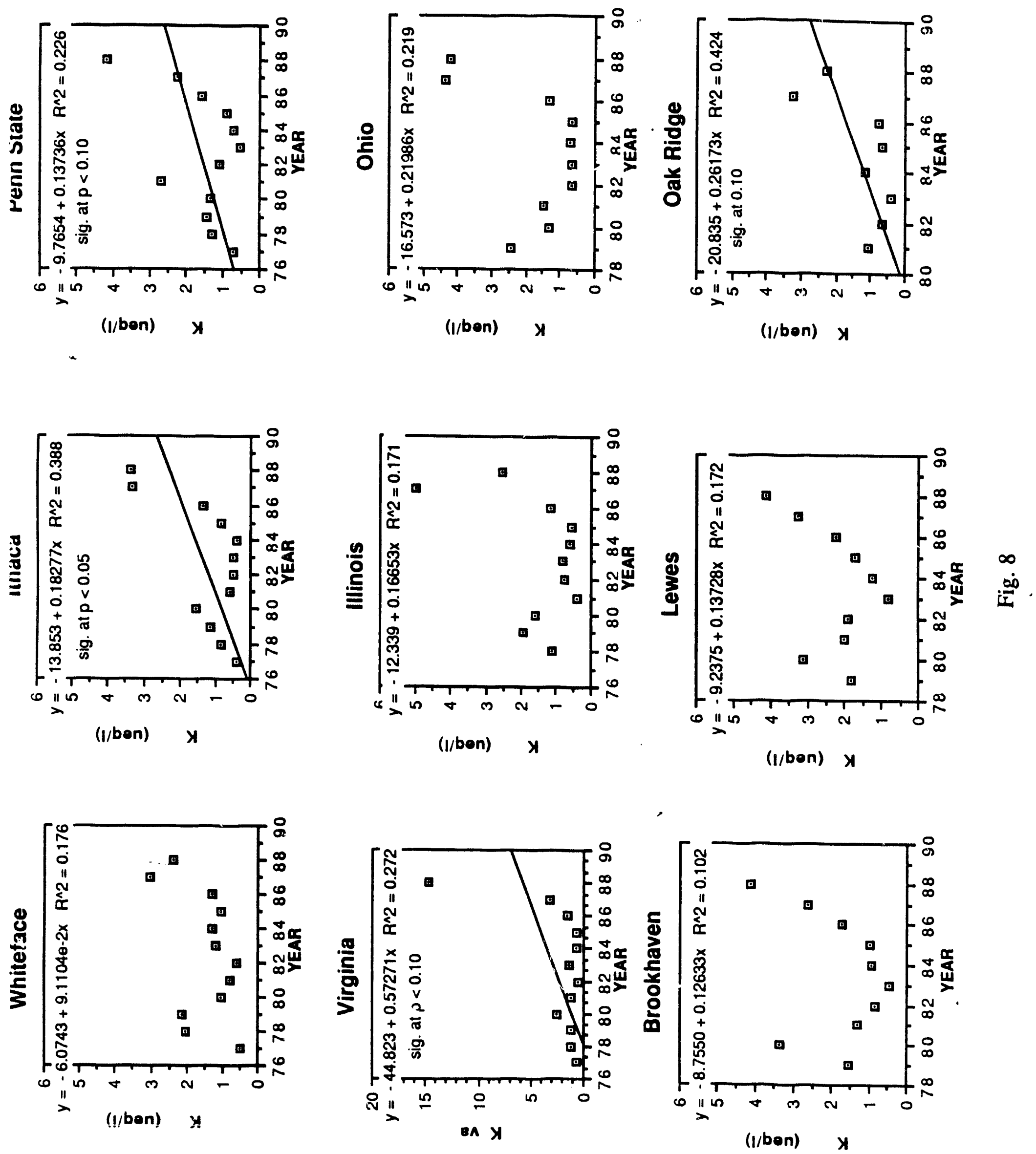

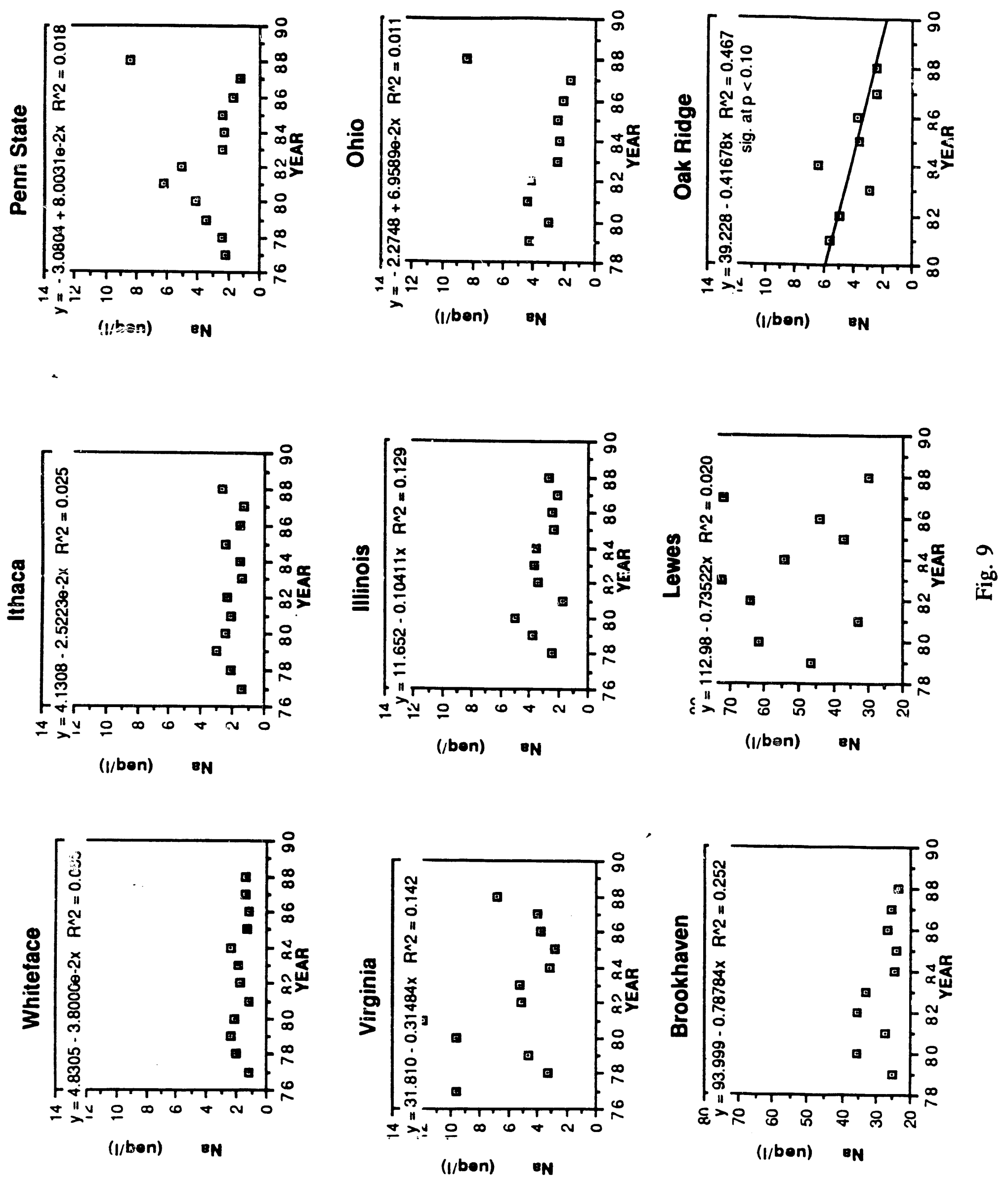


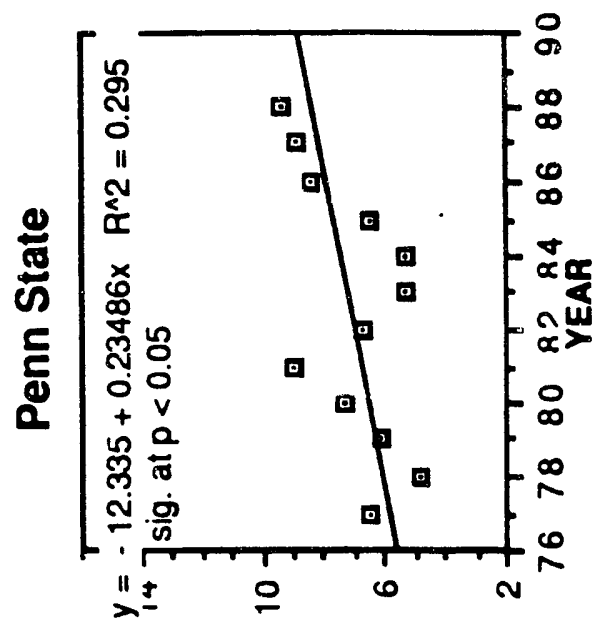

(i/bon) 10
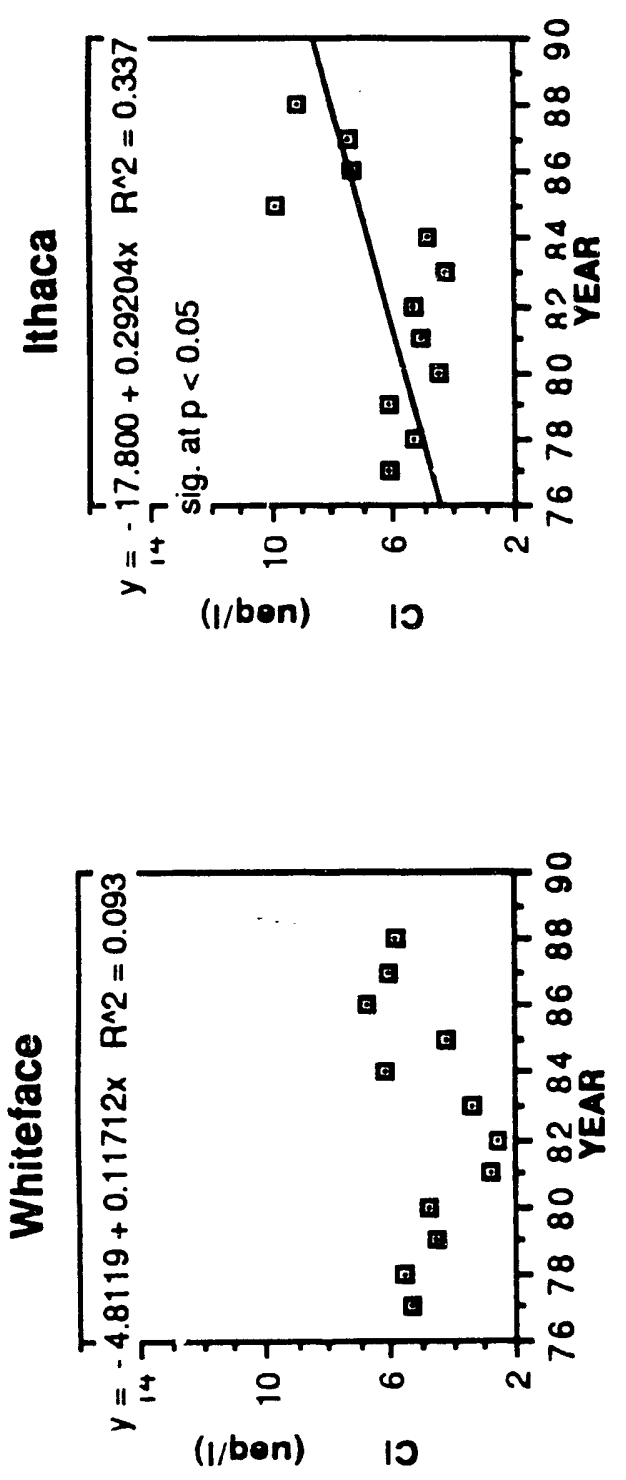
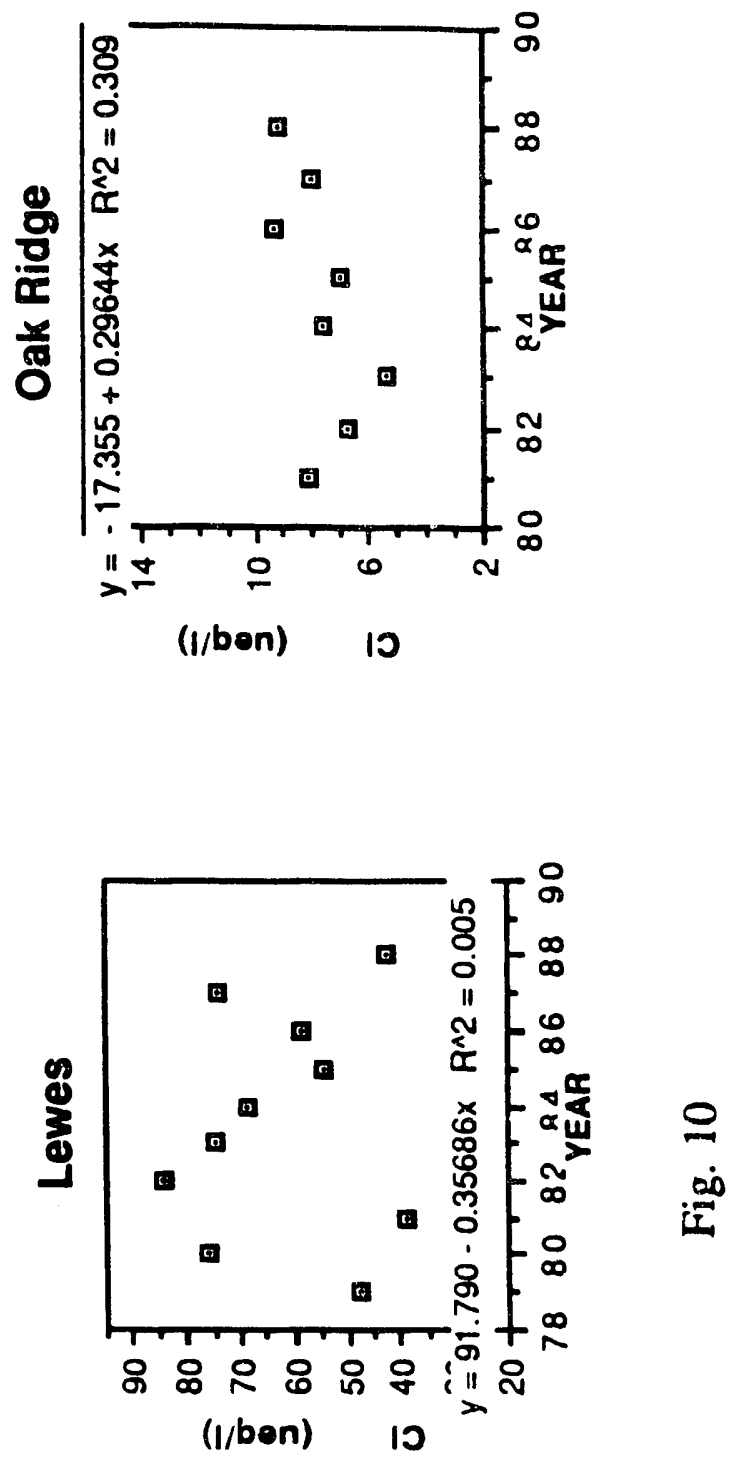

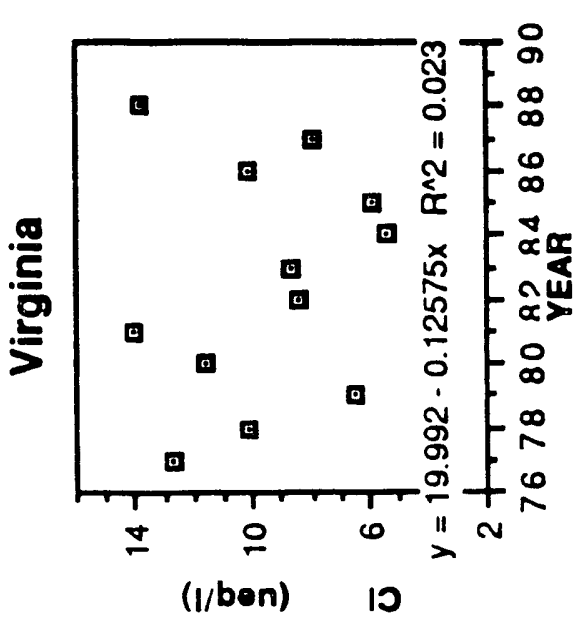

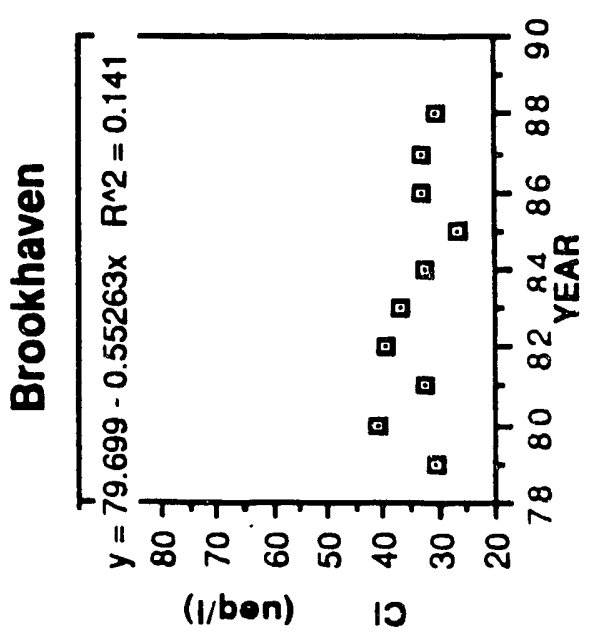




\section{SO2 Emissions}

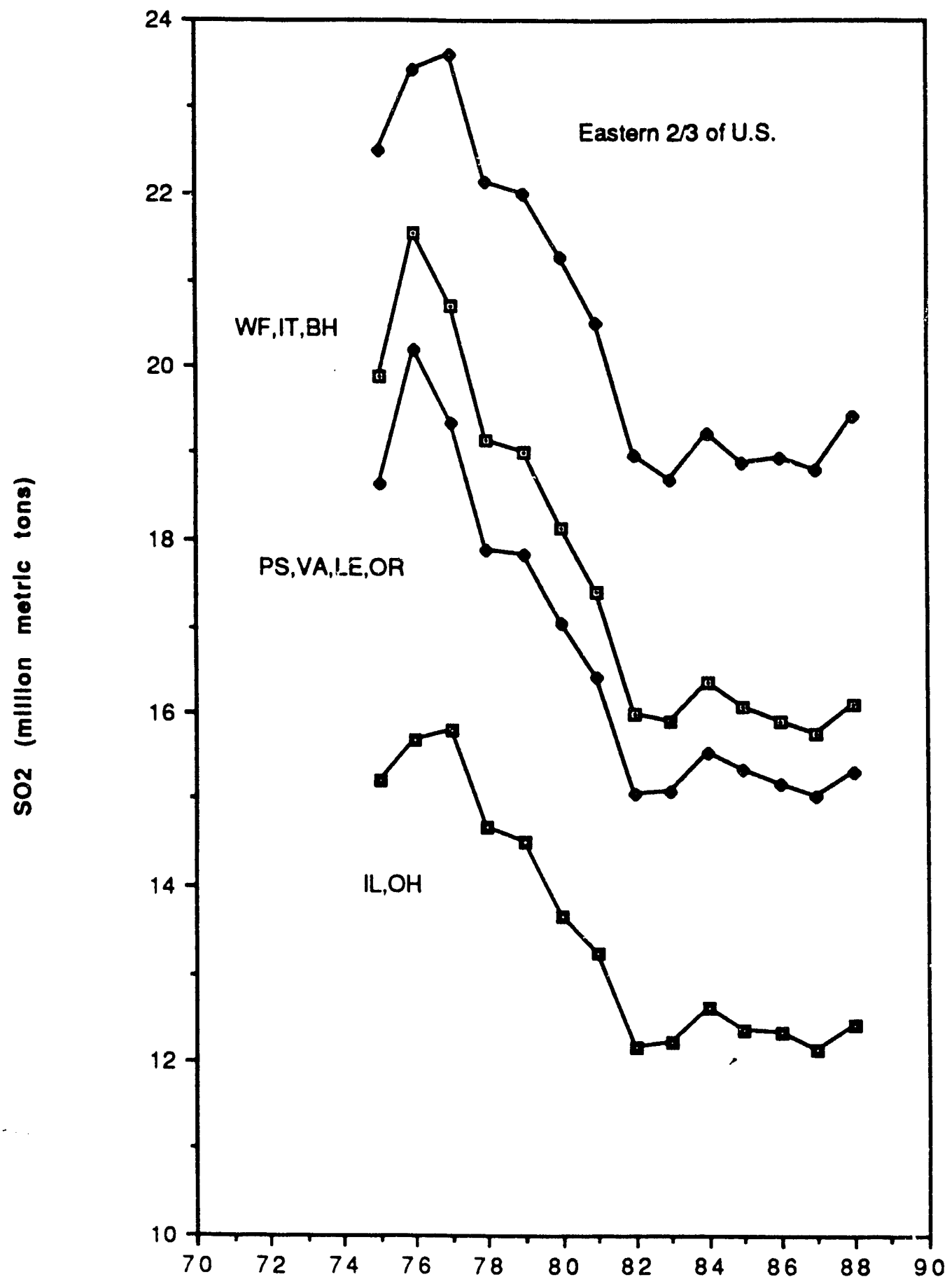

YEAR

Fig. 11 
NOx Emissions

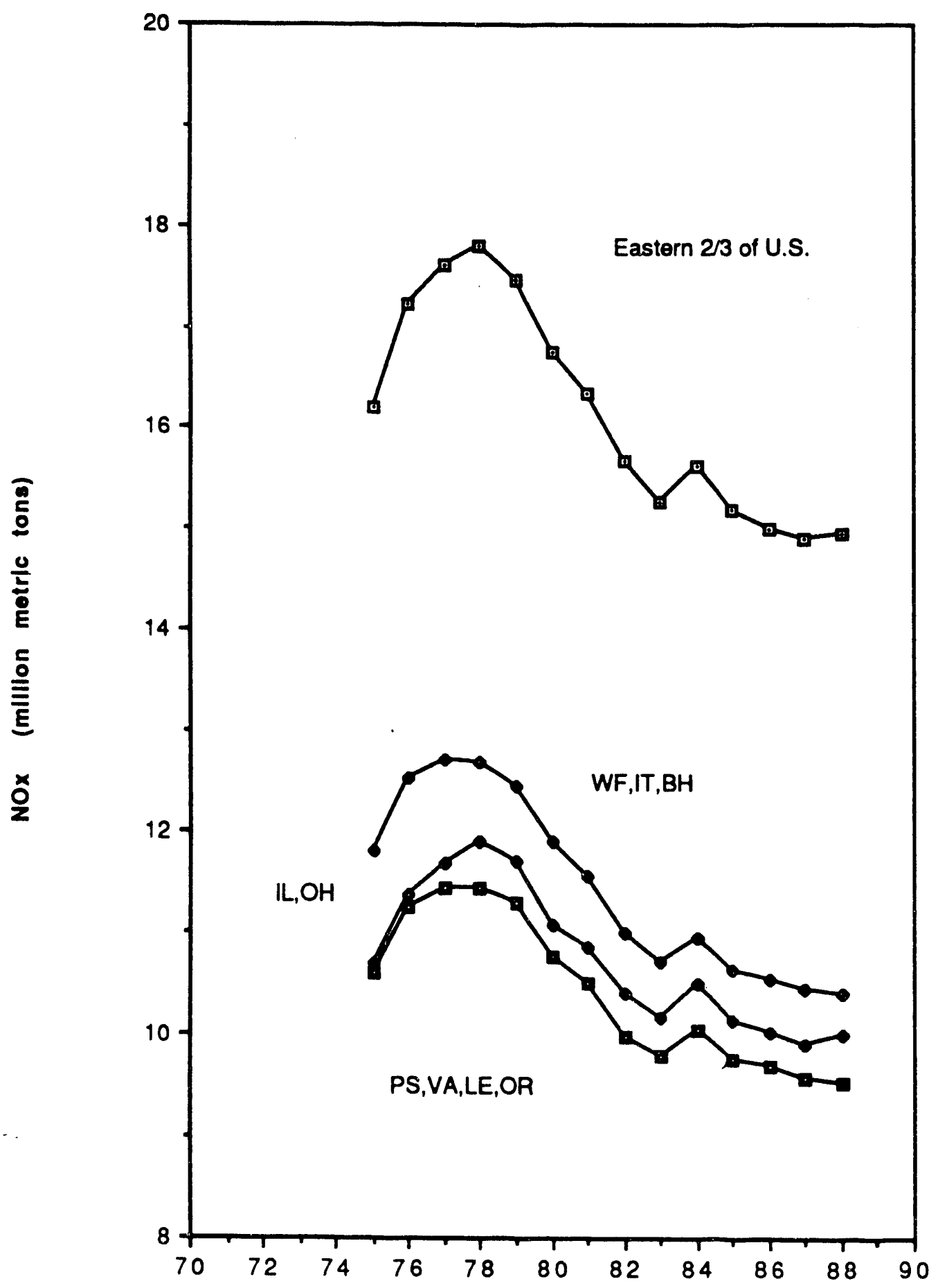

YEAR

Fig. 12 

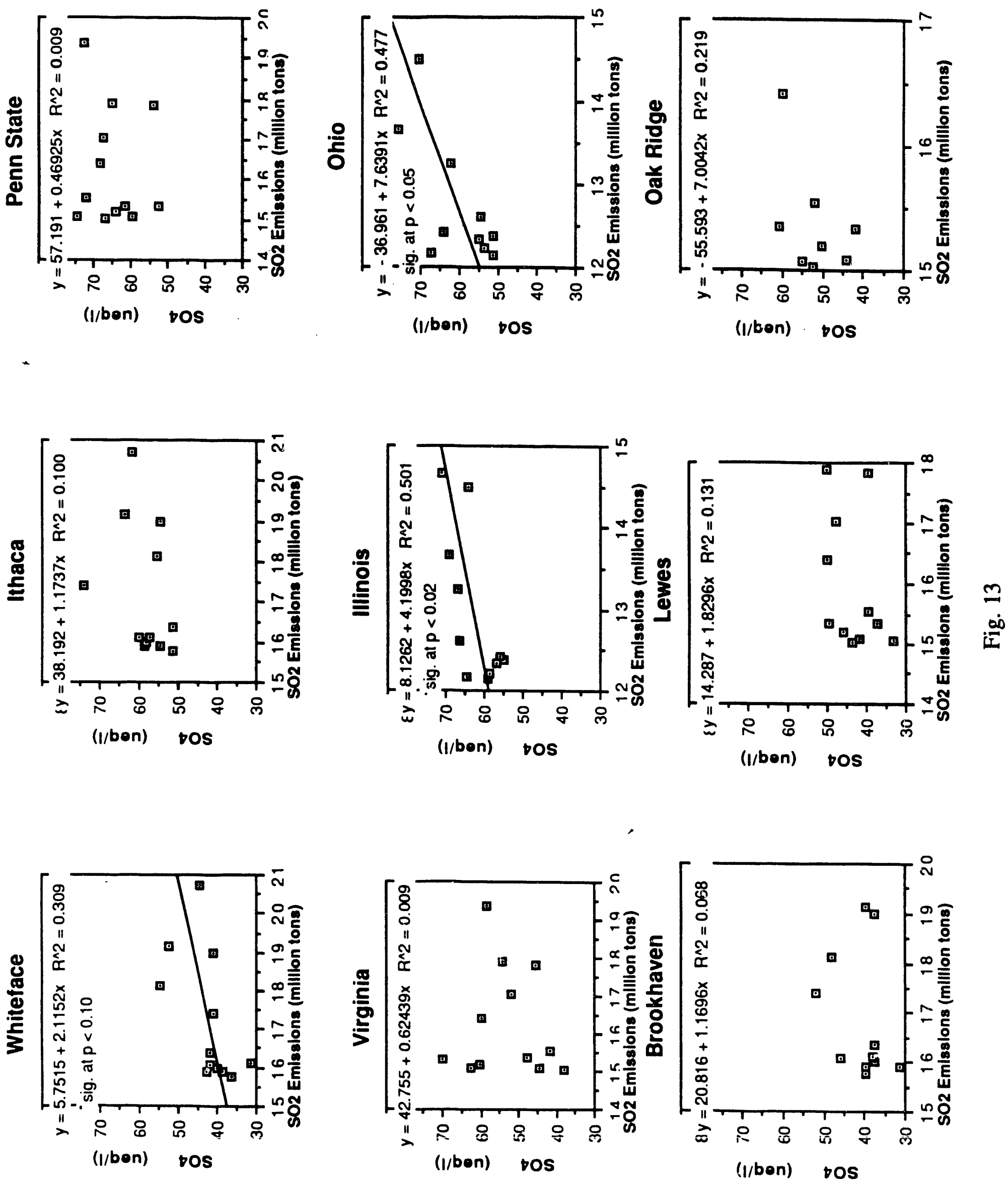
(a)

SO2 vs SO4 for all sites through 1988

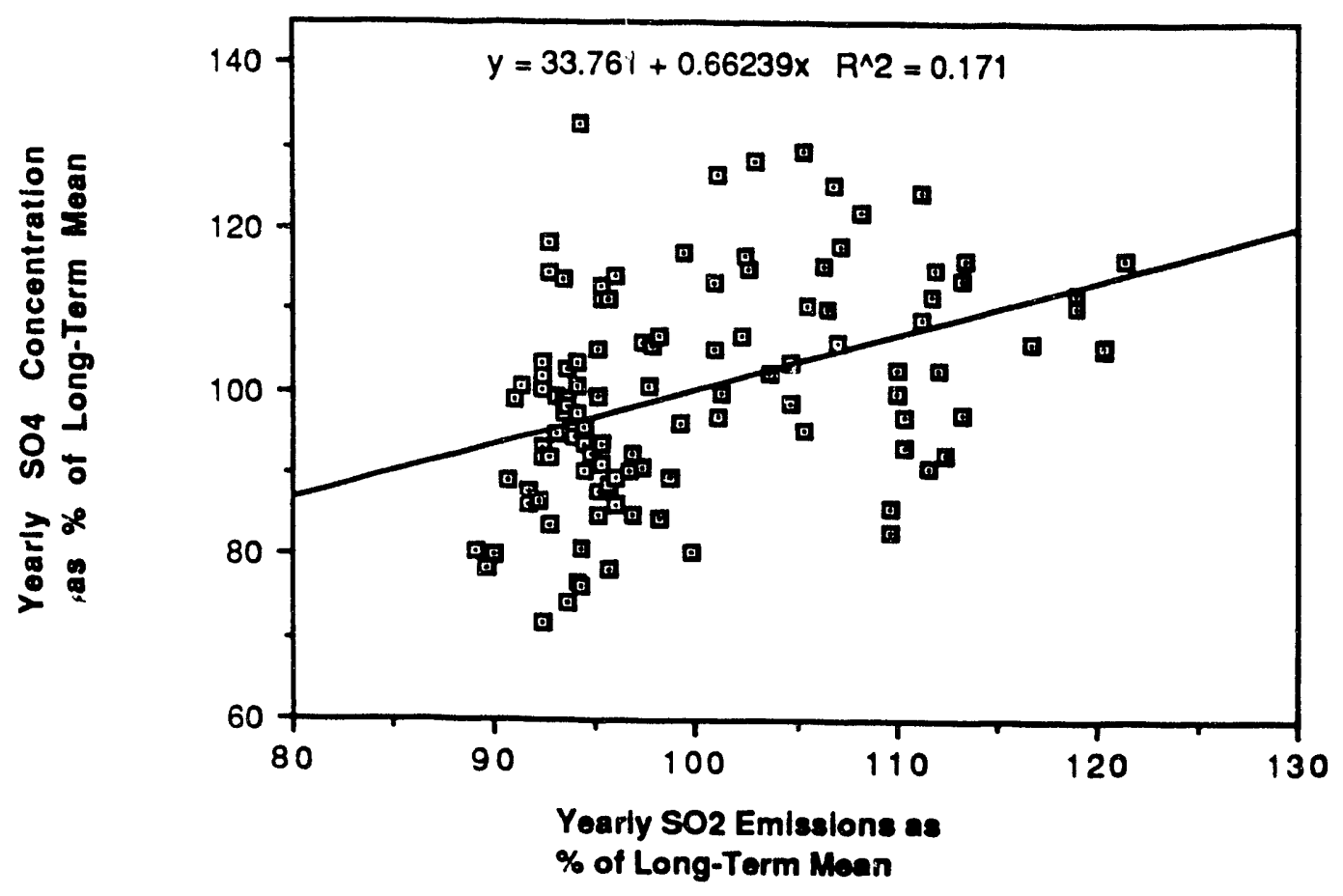

(b)

SO2 + NOx vs. H+ for all sites through 1988

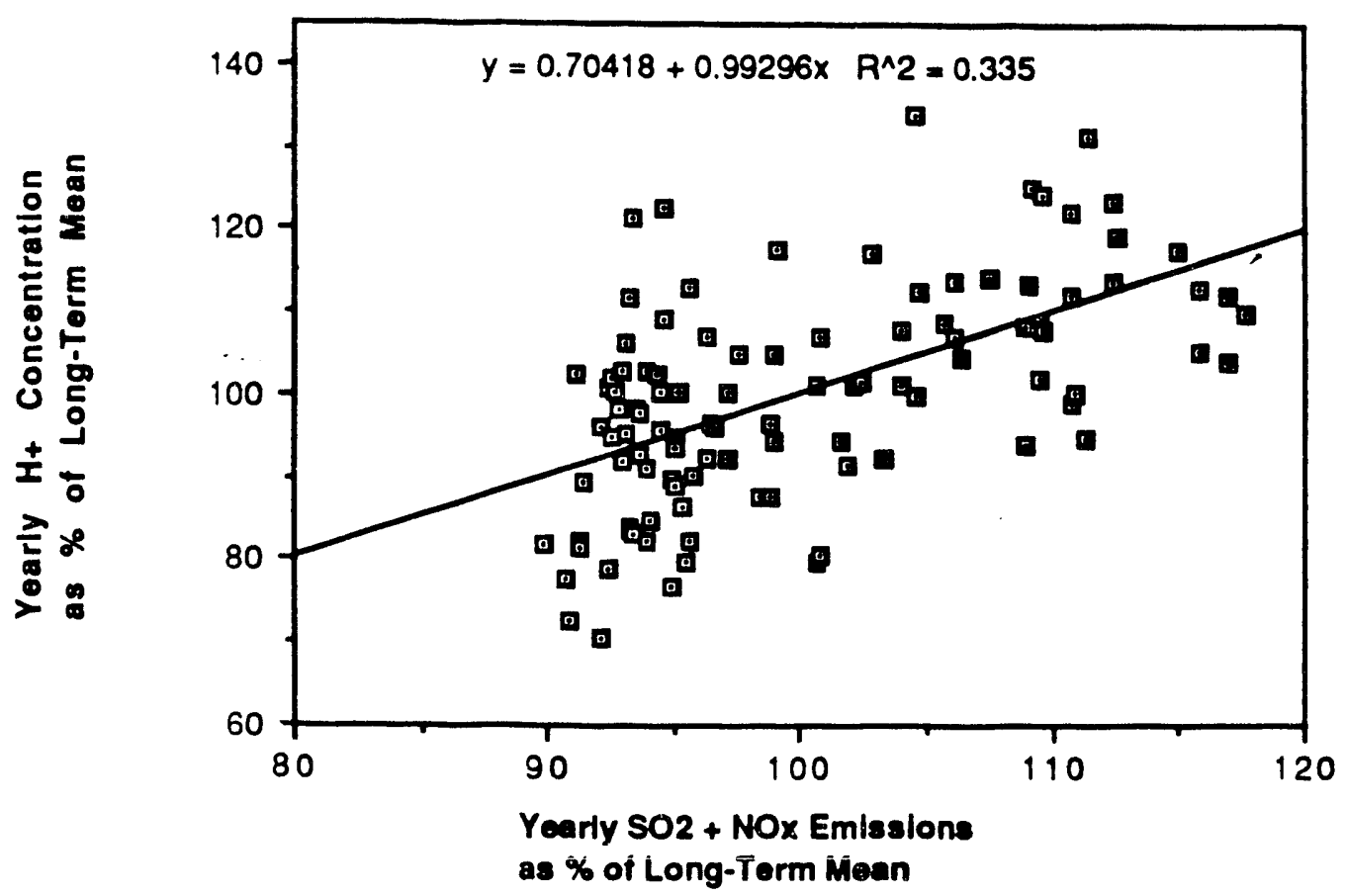

Fig. 14 


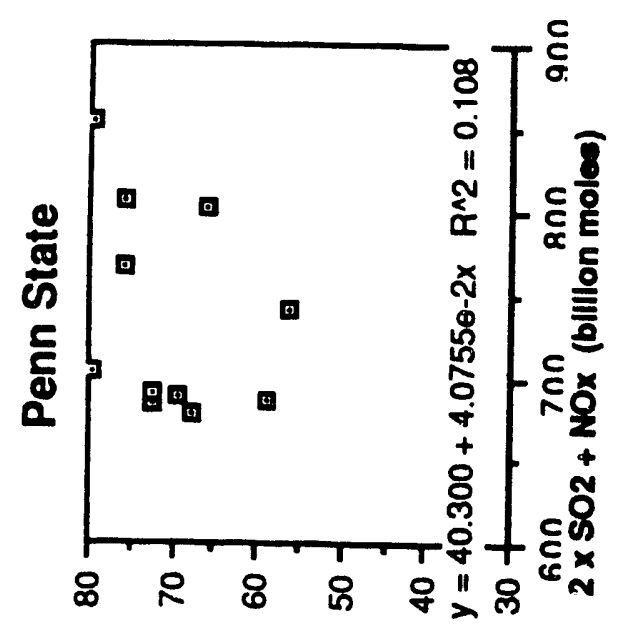

(1/bon) $+\mathrm{H}$
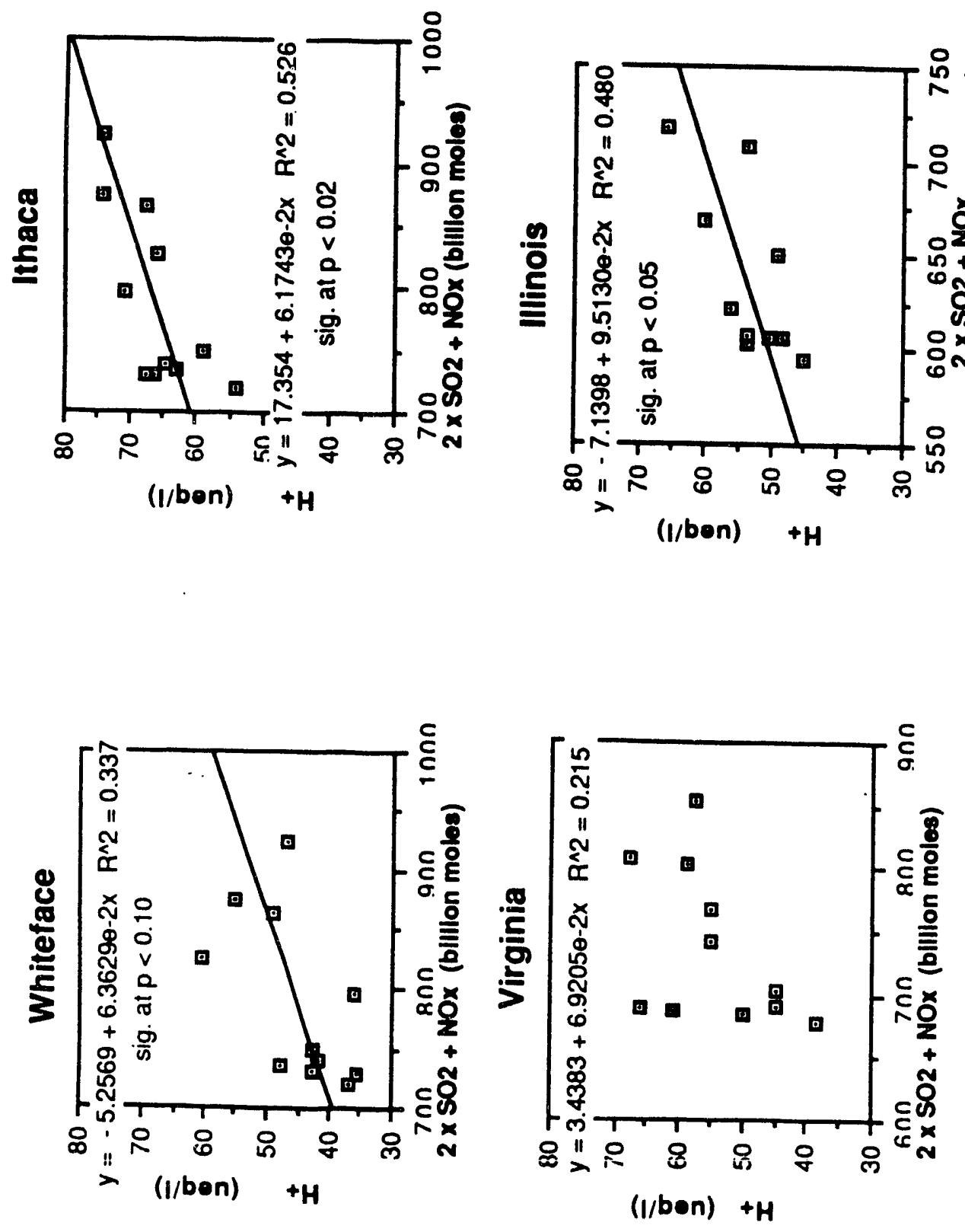
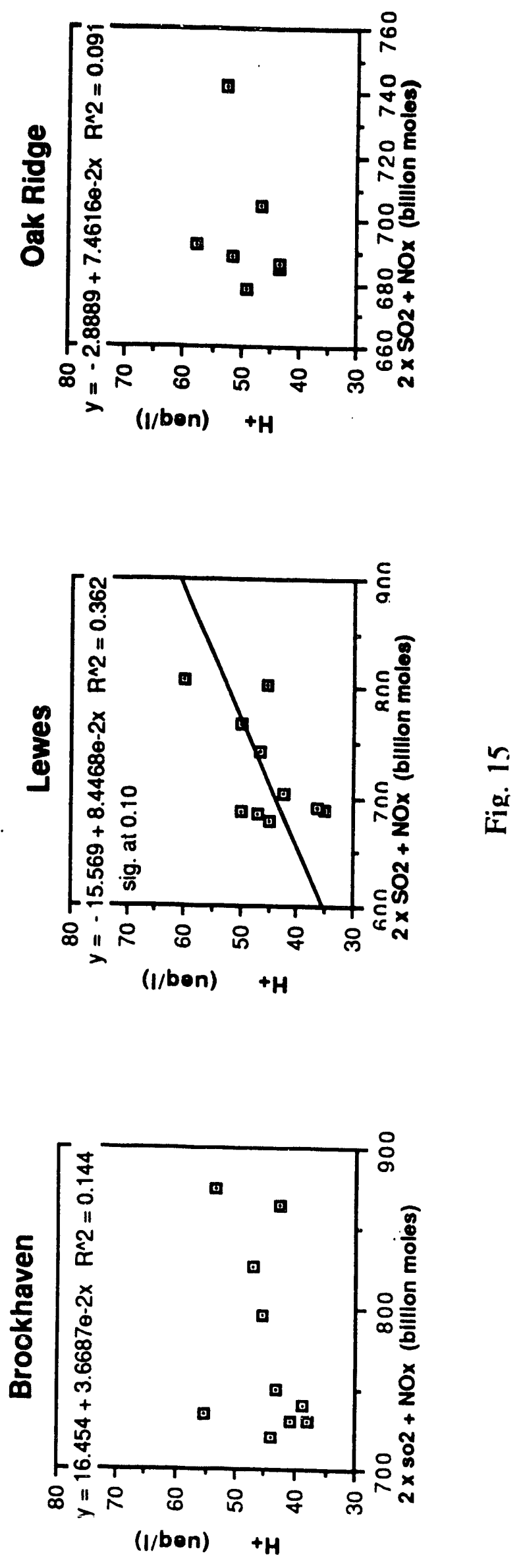


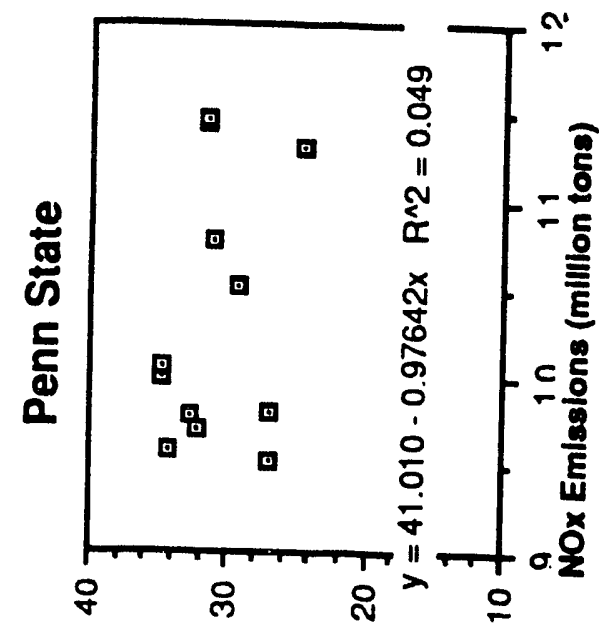

(1/bon) EON
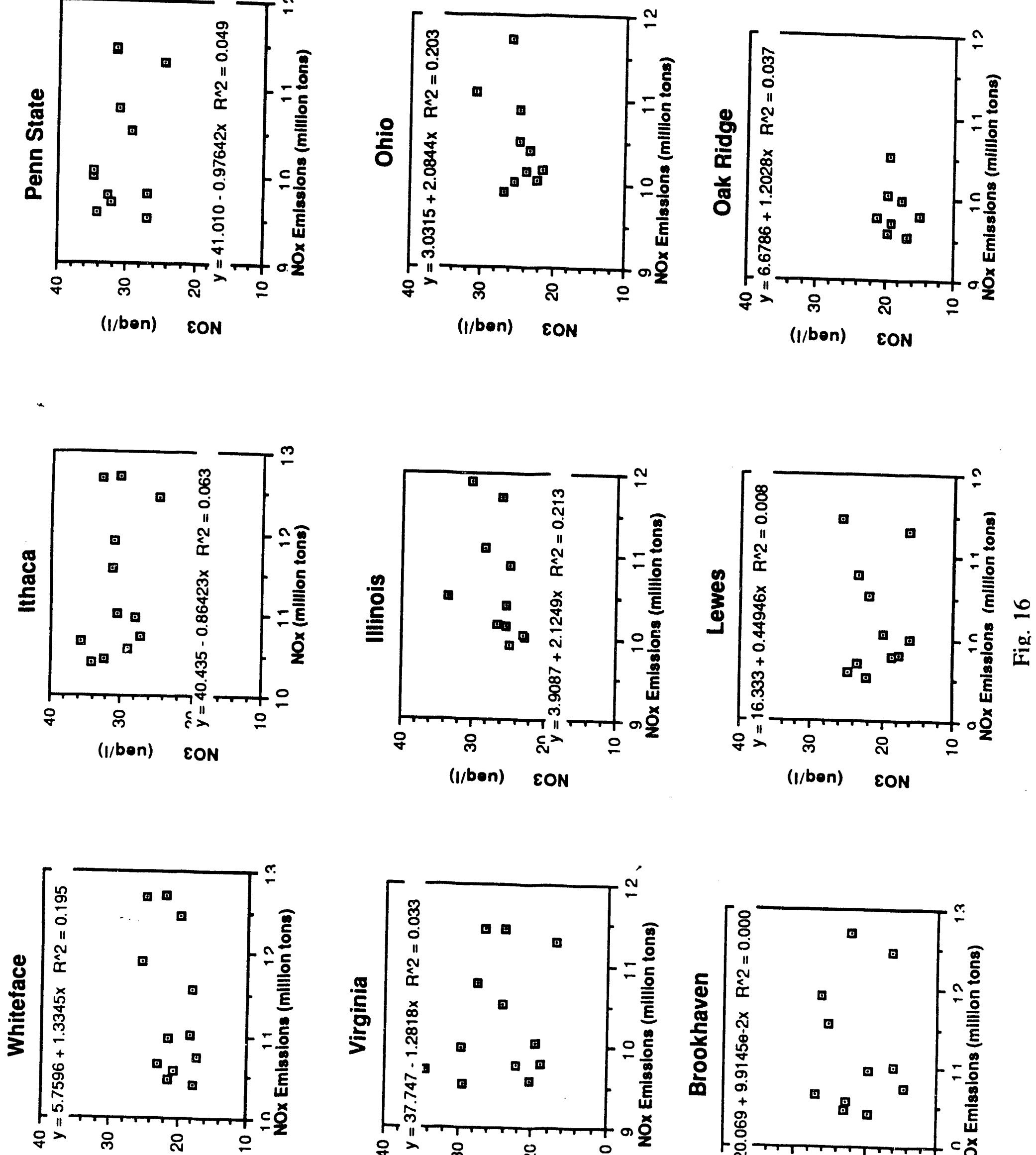

(I/bon) EON
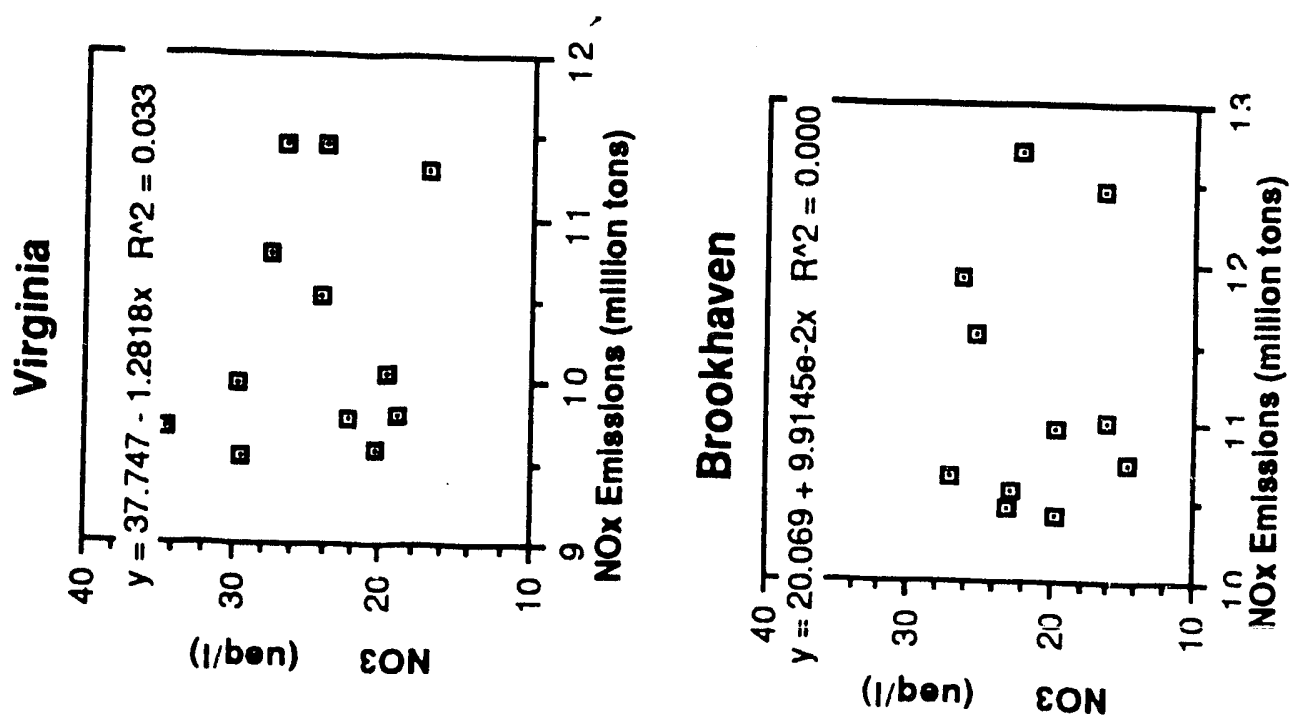


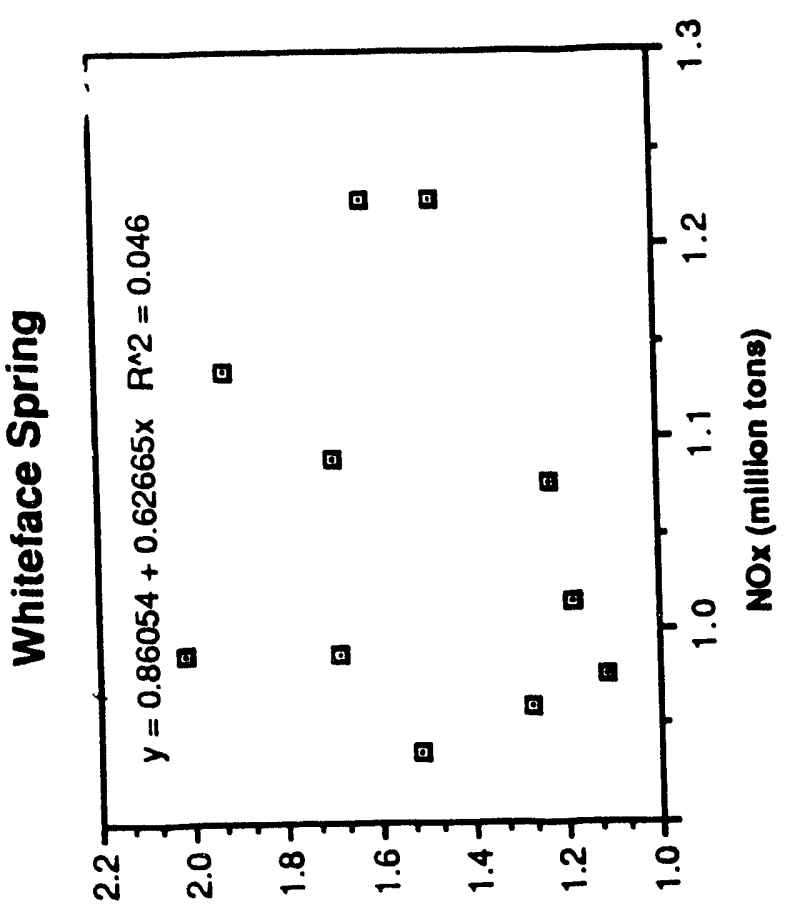

(1/bon) EON

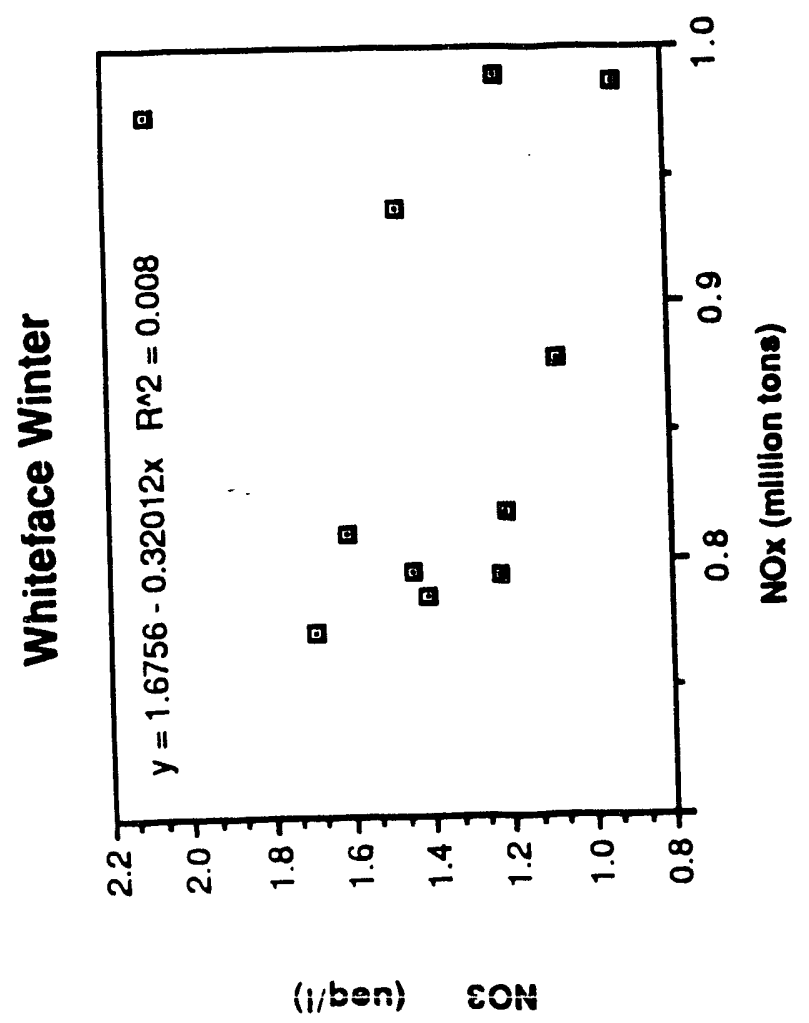

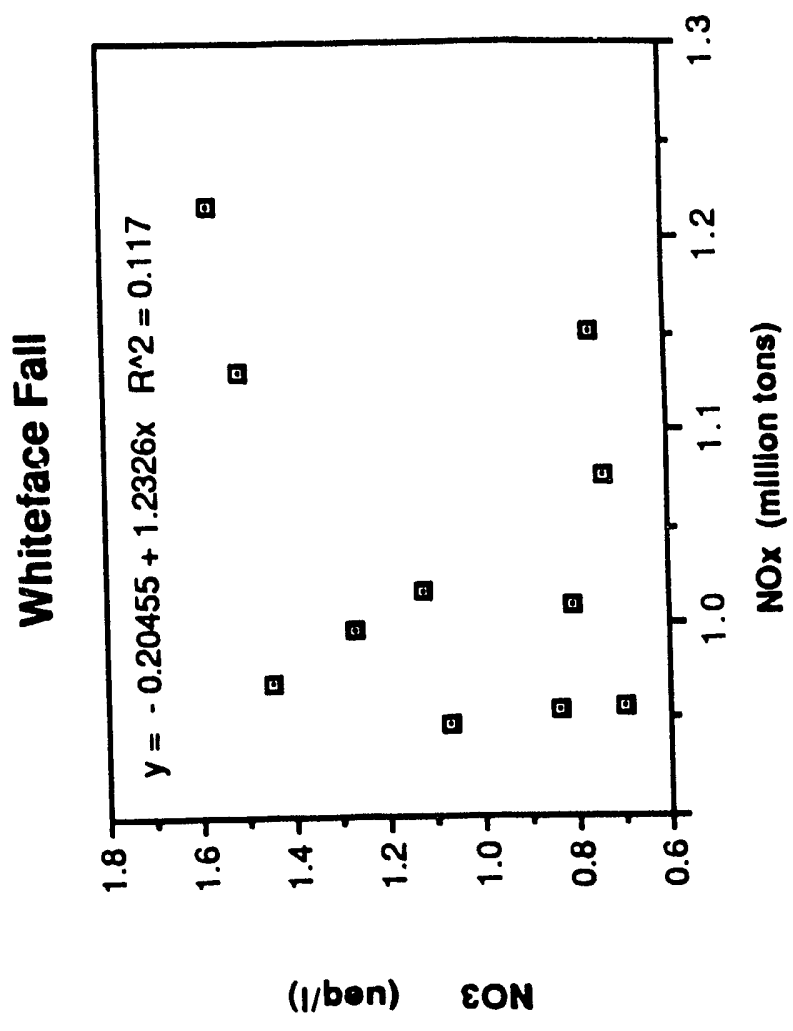

$\stackrel{D}{\dot{0}}$

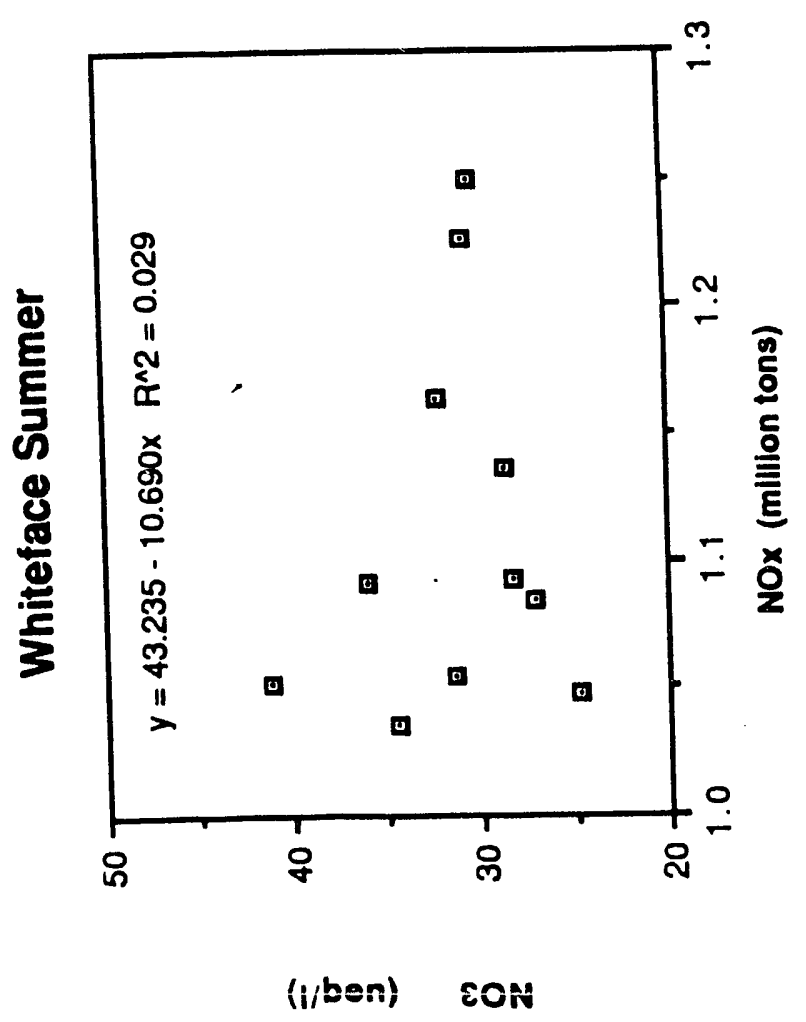




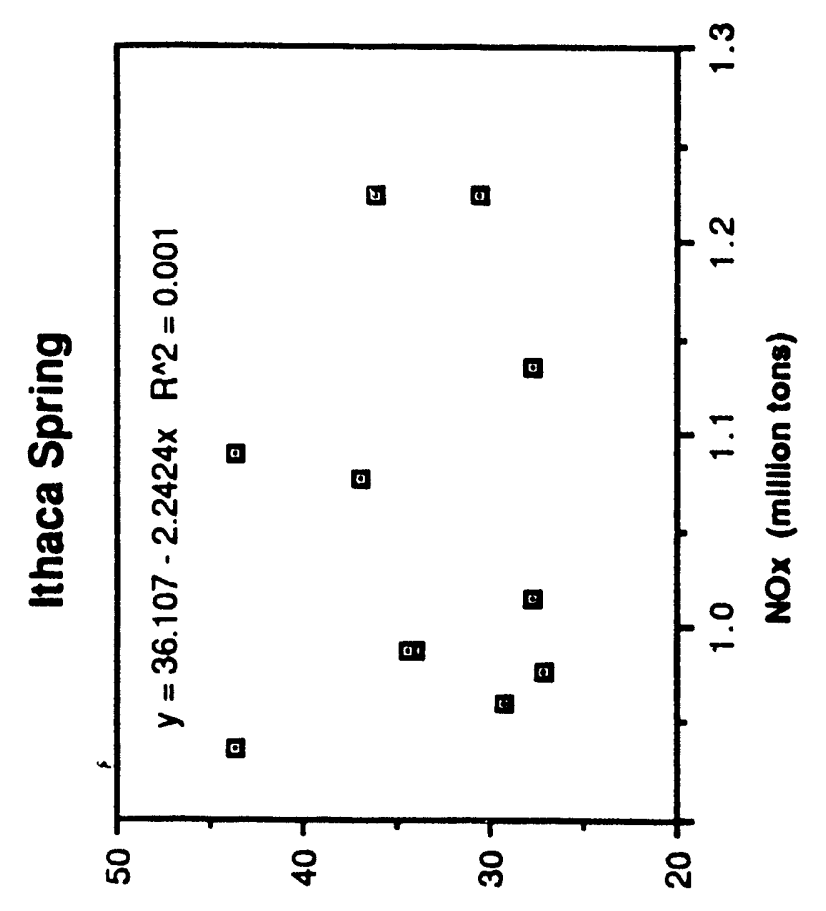

(1/bon) EON

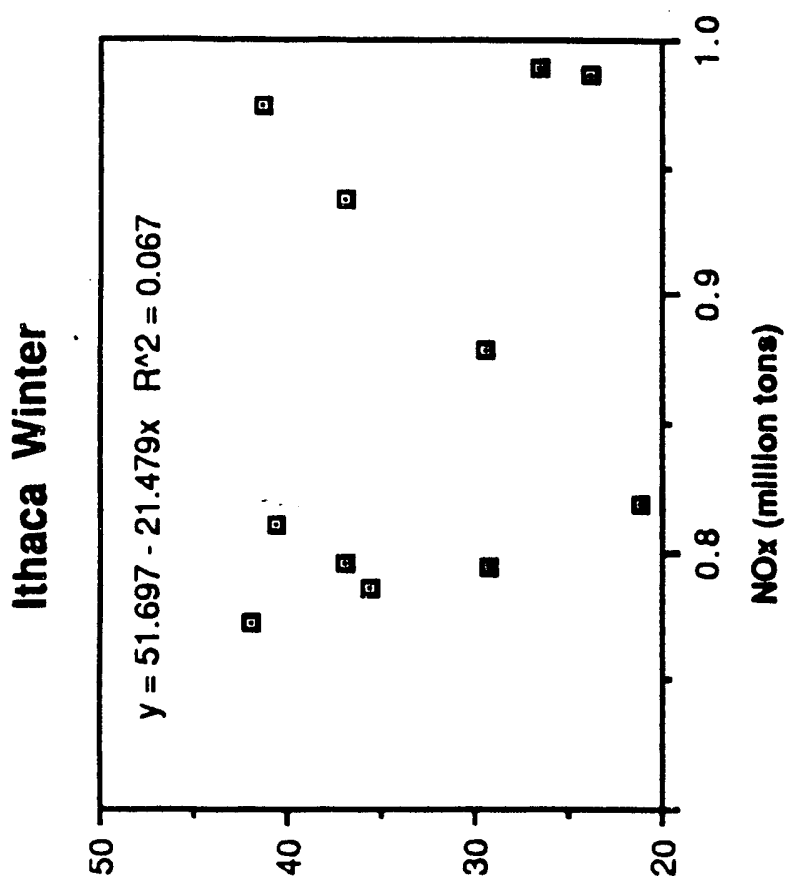

(I/ben) EON

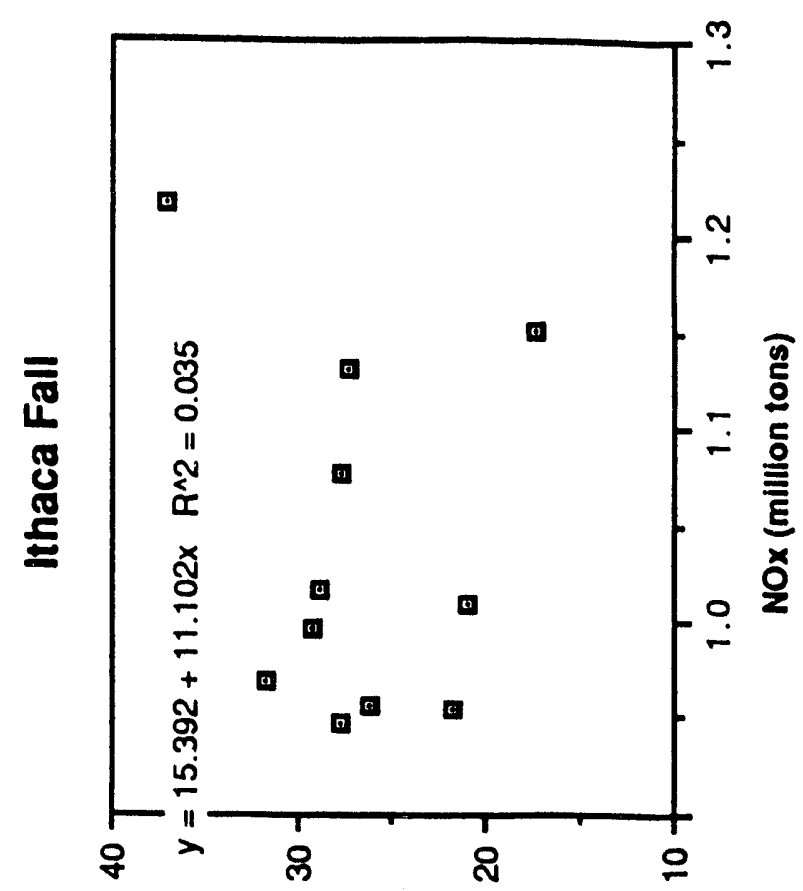

IIEJ EON H

$\stackrel{\infty}{\stackrel{\infty}{10}}$

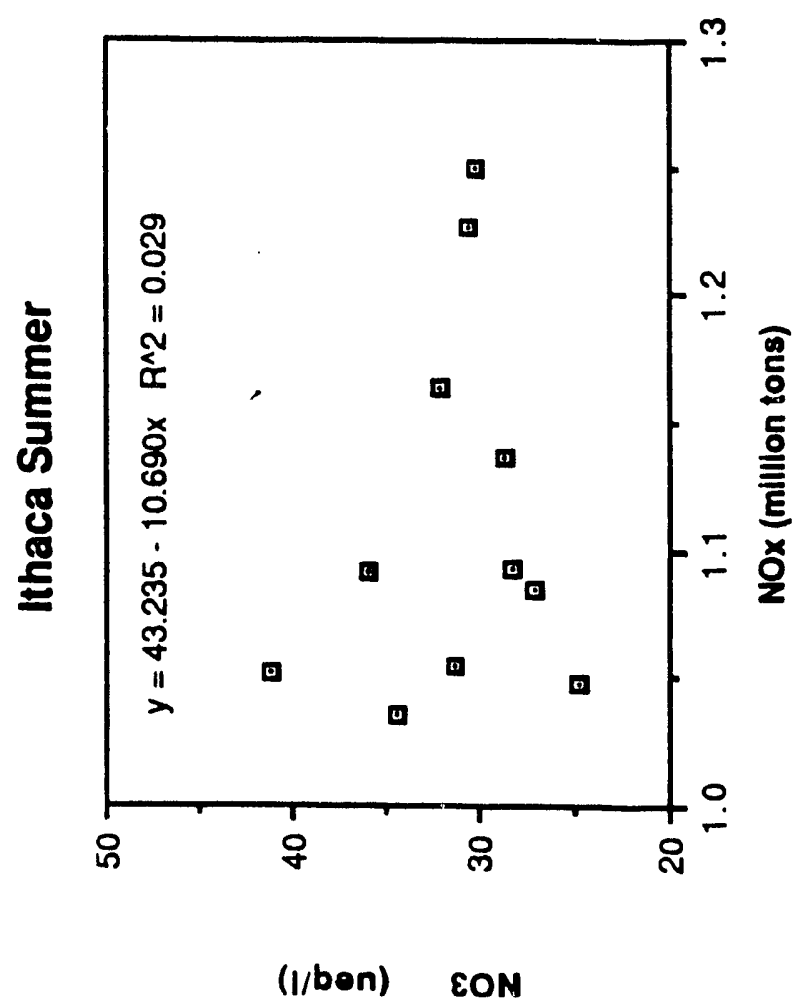




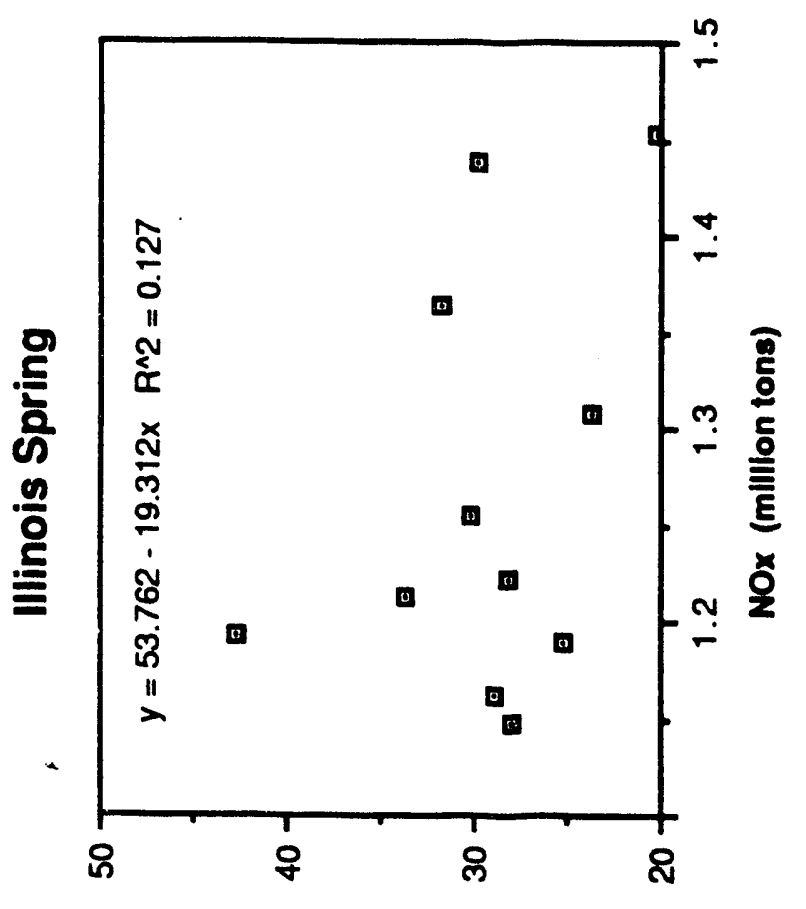

(1/ben) EON

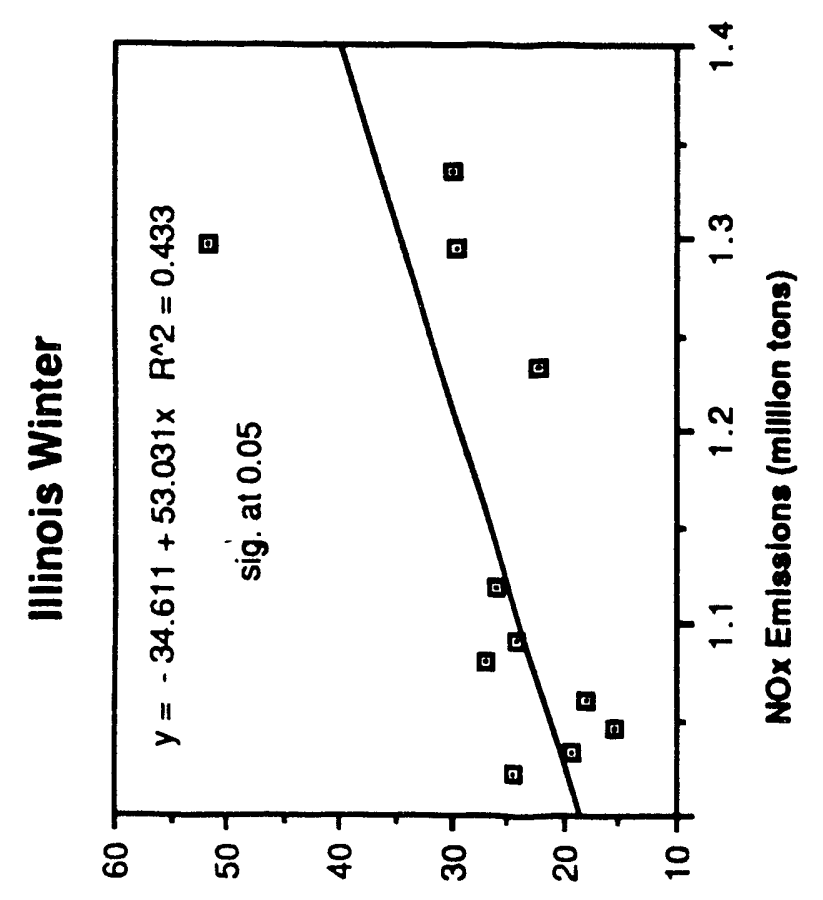

(1/ben) EON

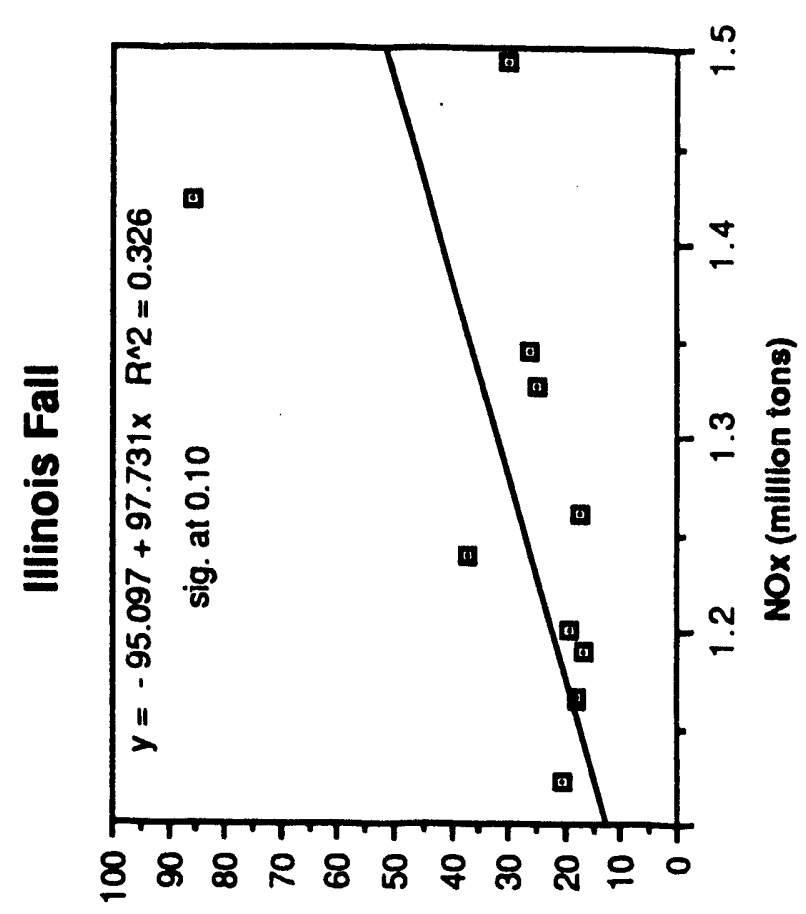

(1/bon) EON

2

茫

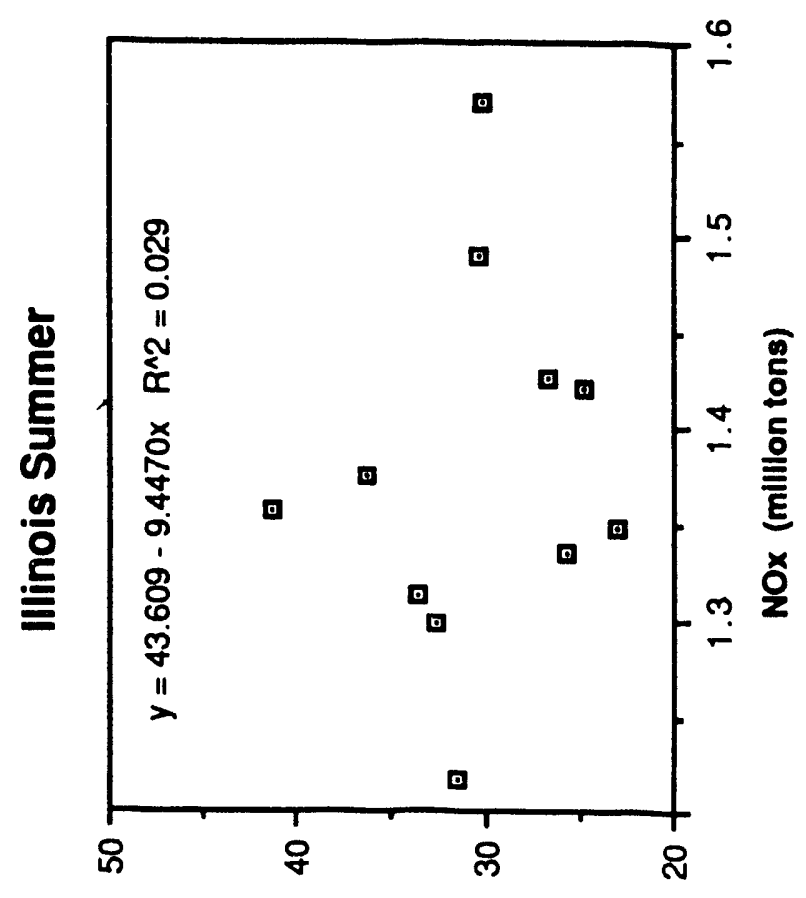

(l/bon) EON 


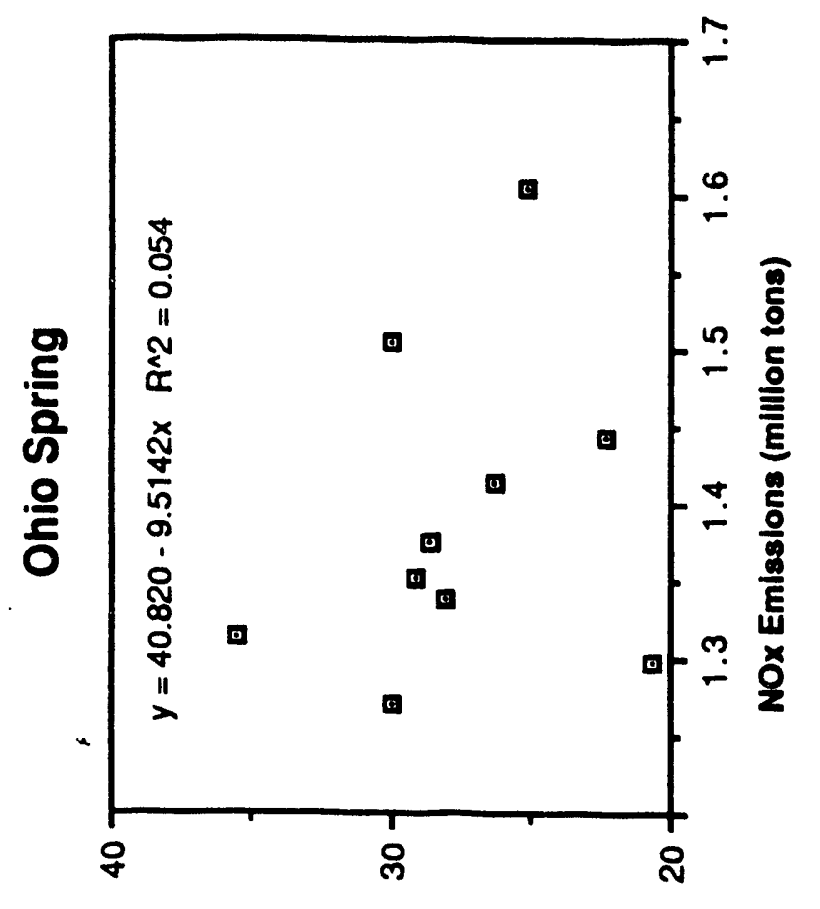

(1/bon) EON

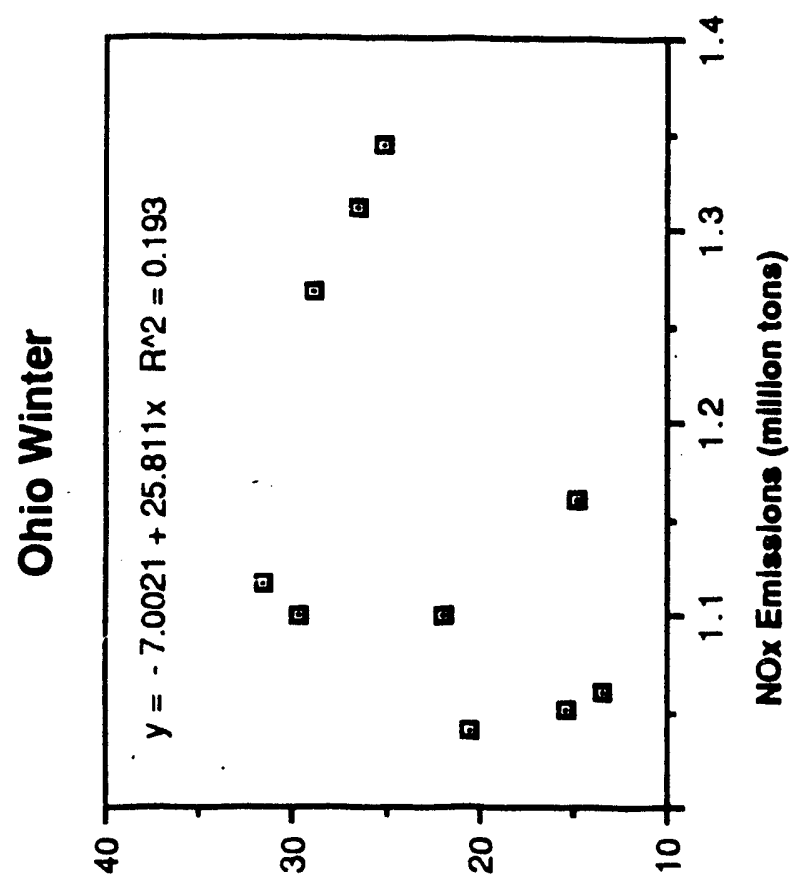

(i/ben) EOA

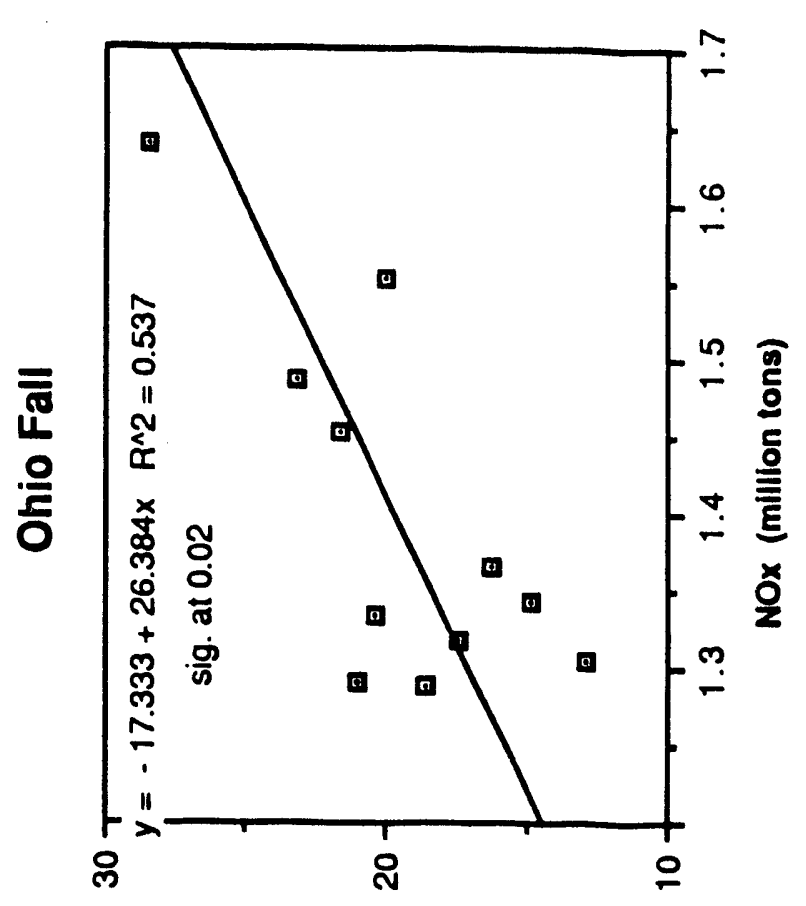

(1/bon) EON

ิㅗ

ic

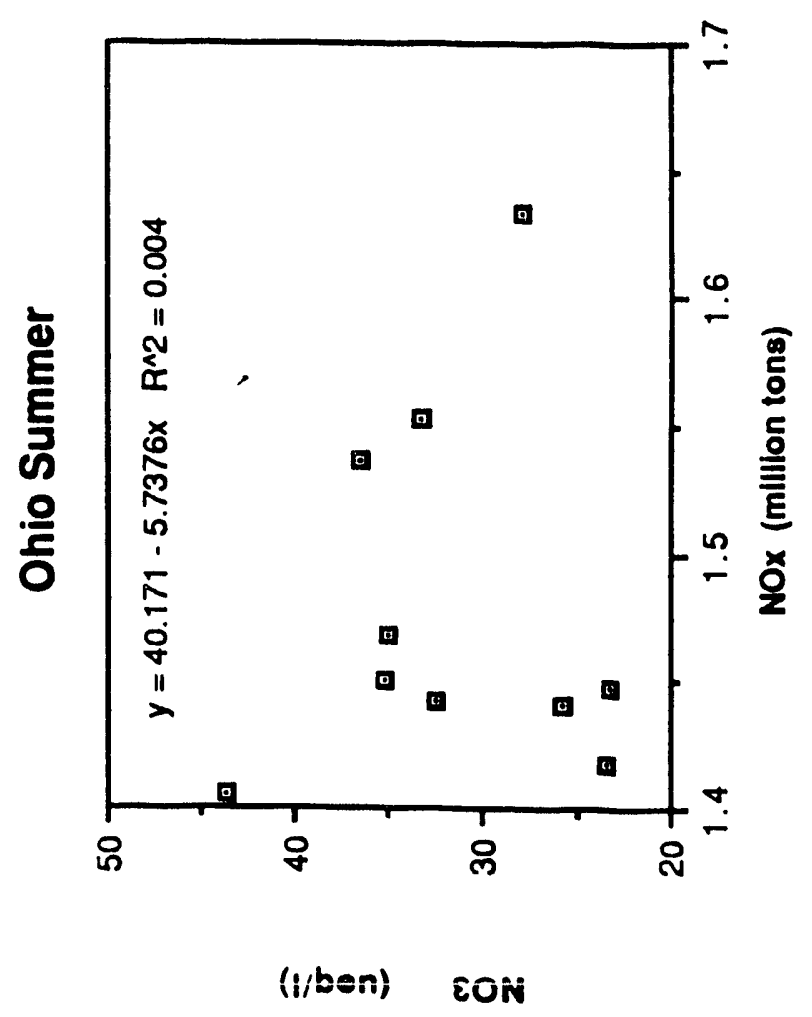




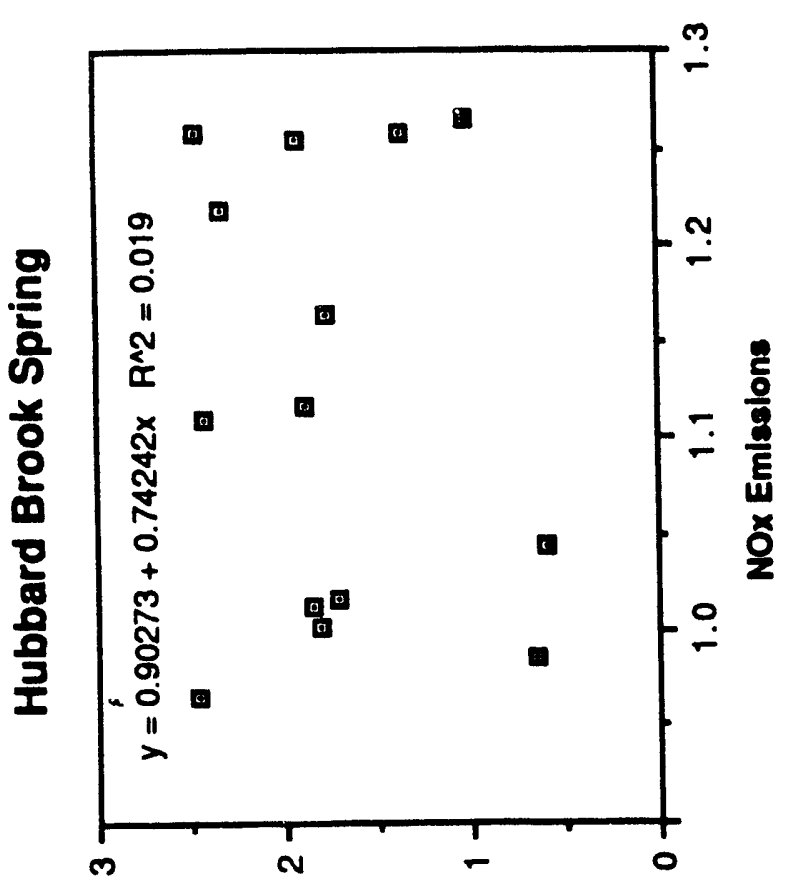

(1/6w) EON

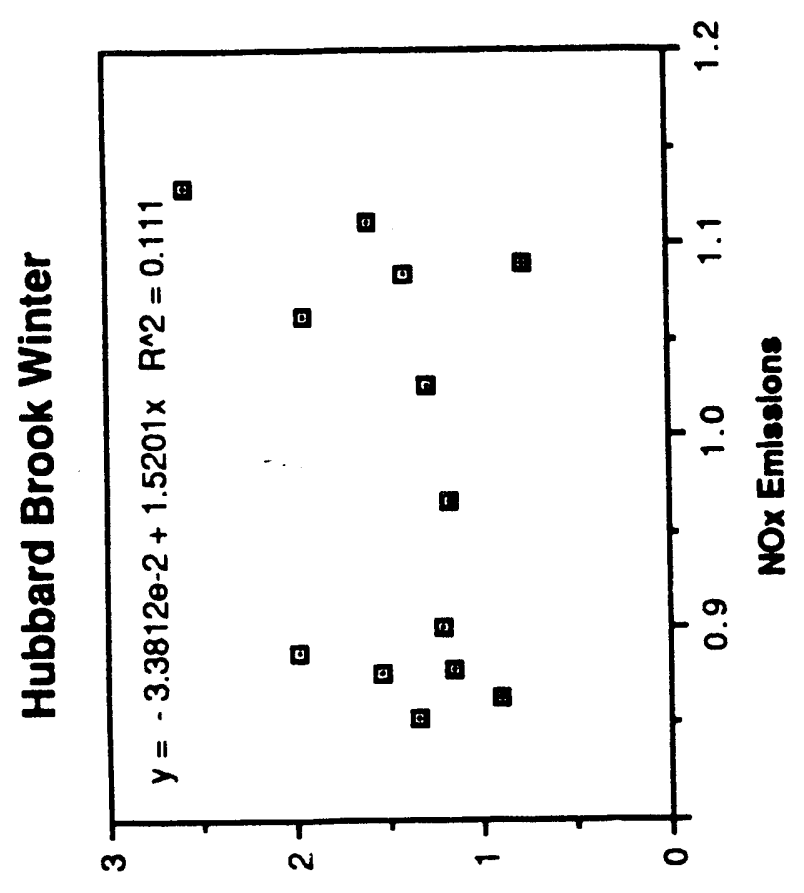

(1/6w) EON

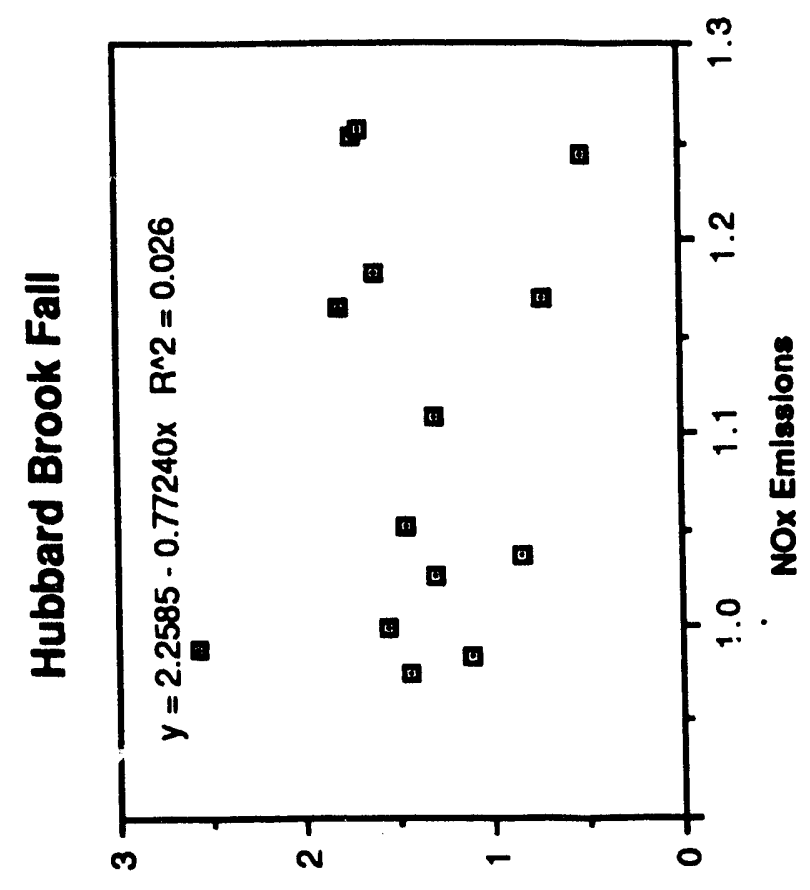

(1/6w) EON

六

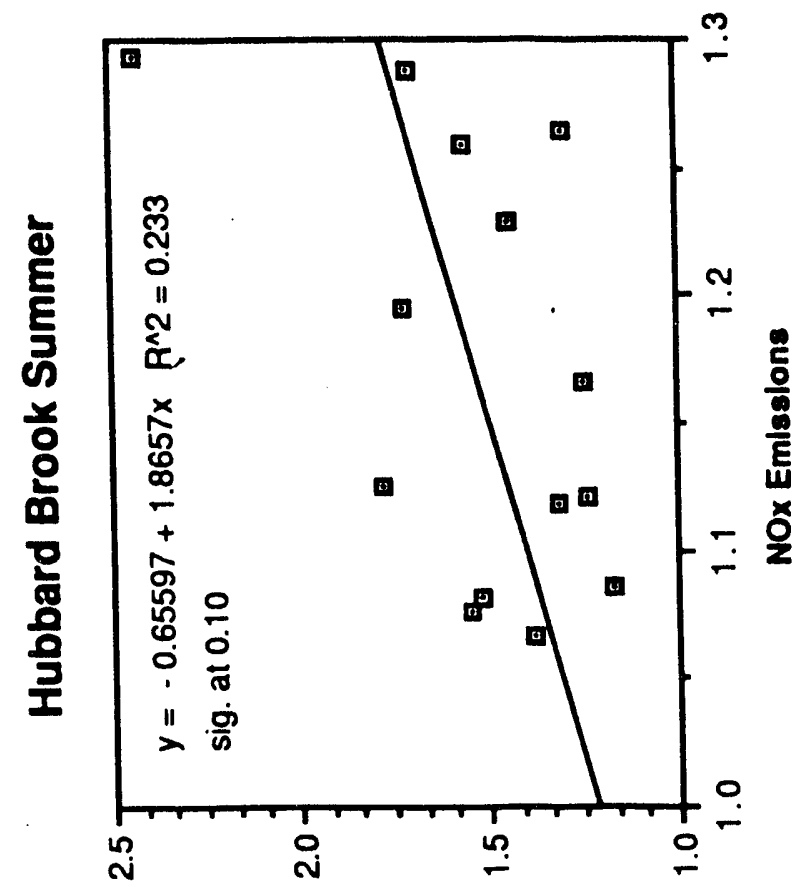

$(1 / 6 w) \quad \varepsilon O N$ 

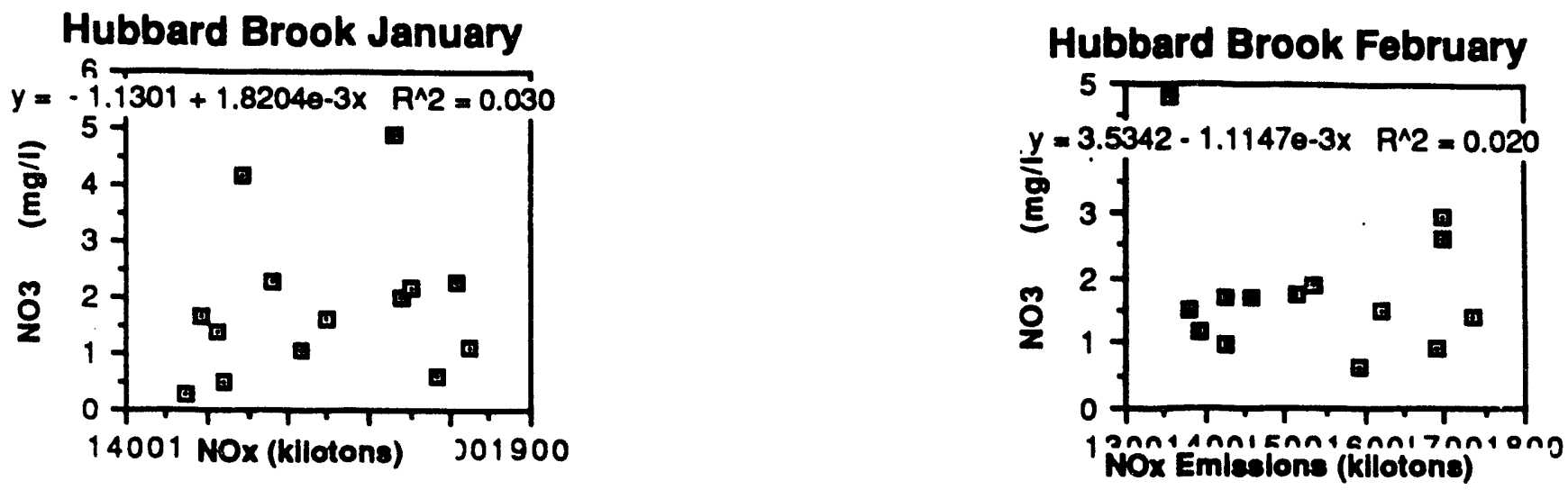

Hubbard Brook March

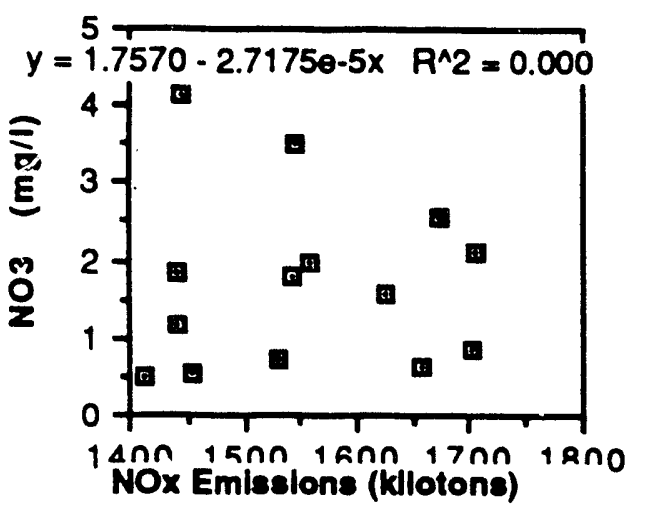

Hubbard Brook April
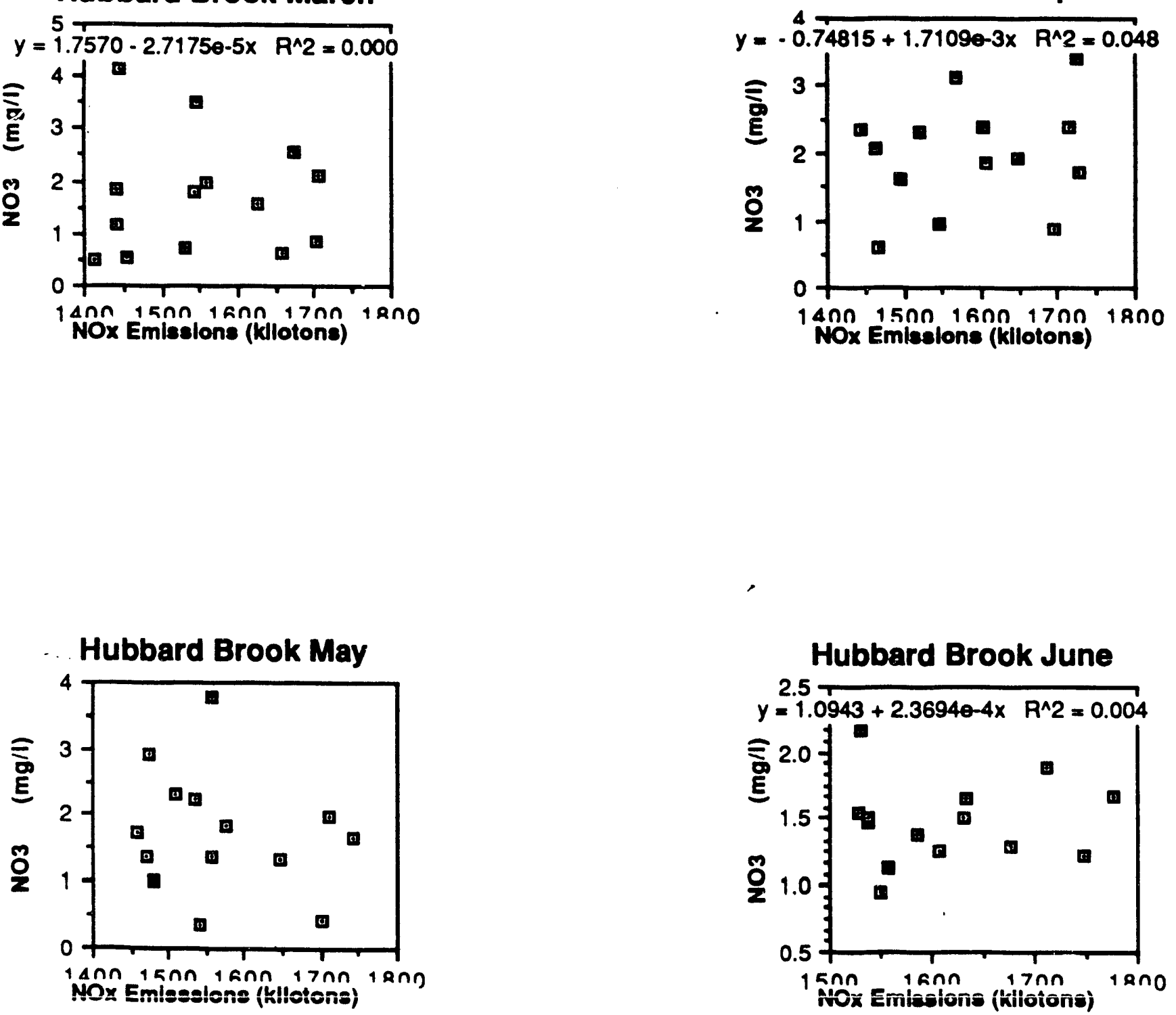

Fig. 22 


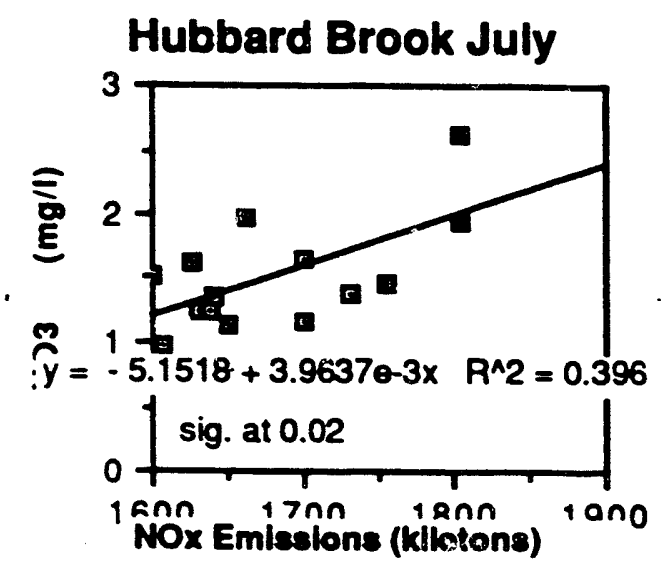

Hubbard Brook August

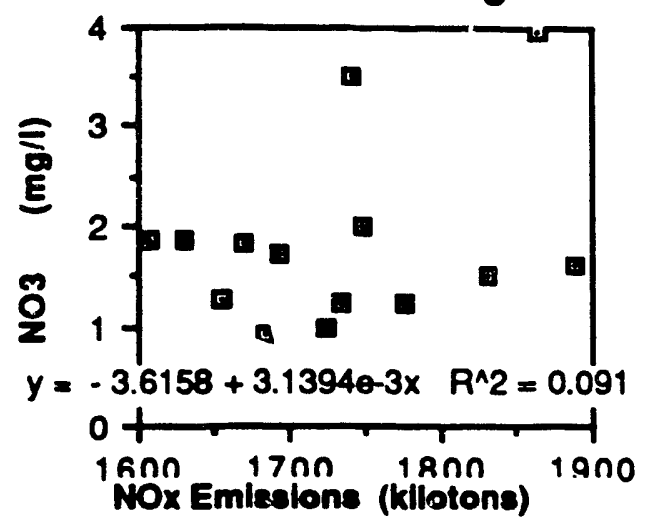

Hubbard Brook September

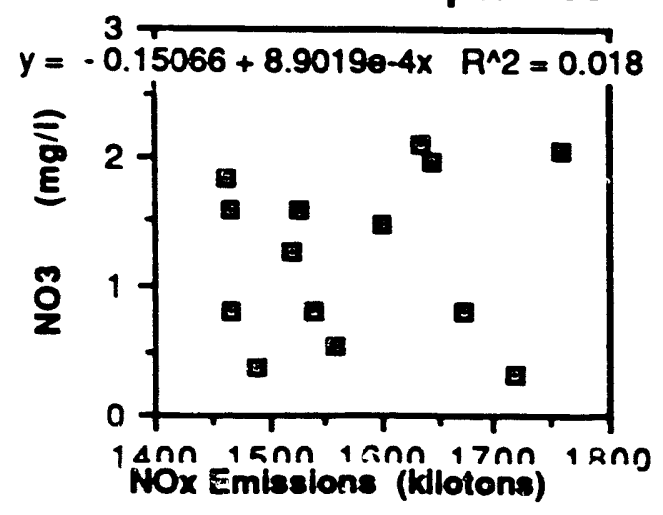

Hubbard Brook October

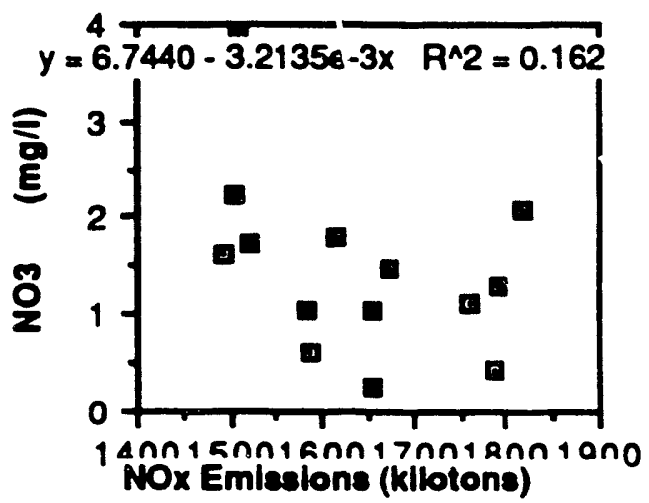

Hubbard Brook November

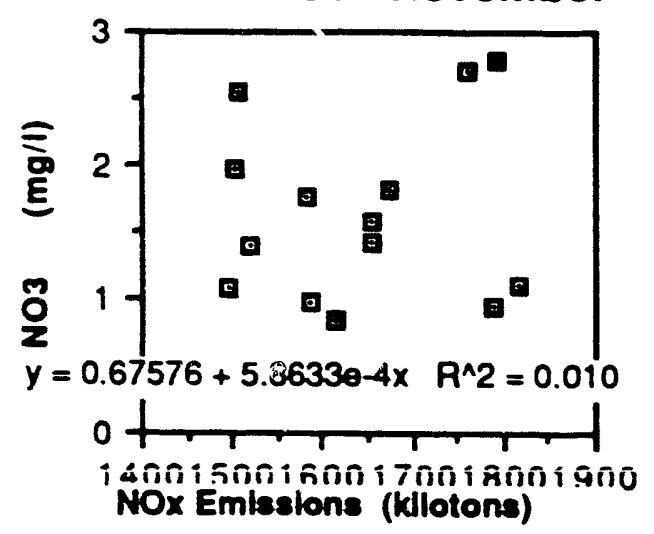

Hubbard Brook December

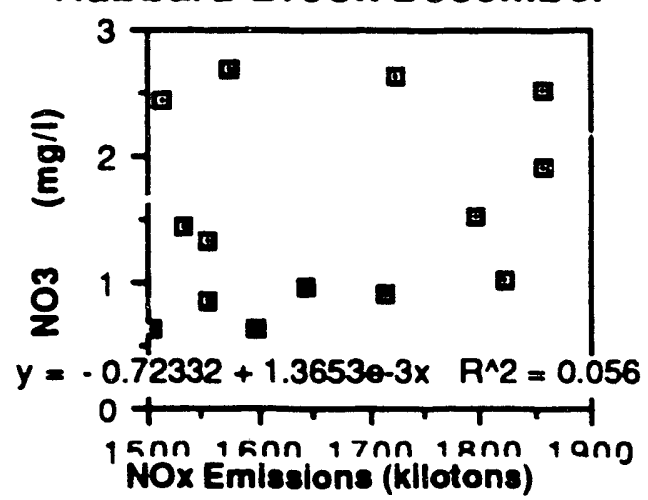

Fig. 23 


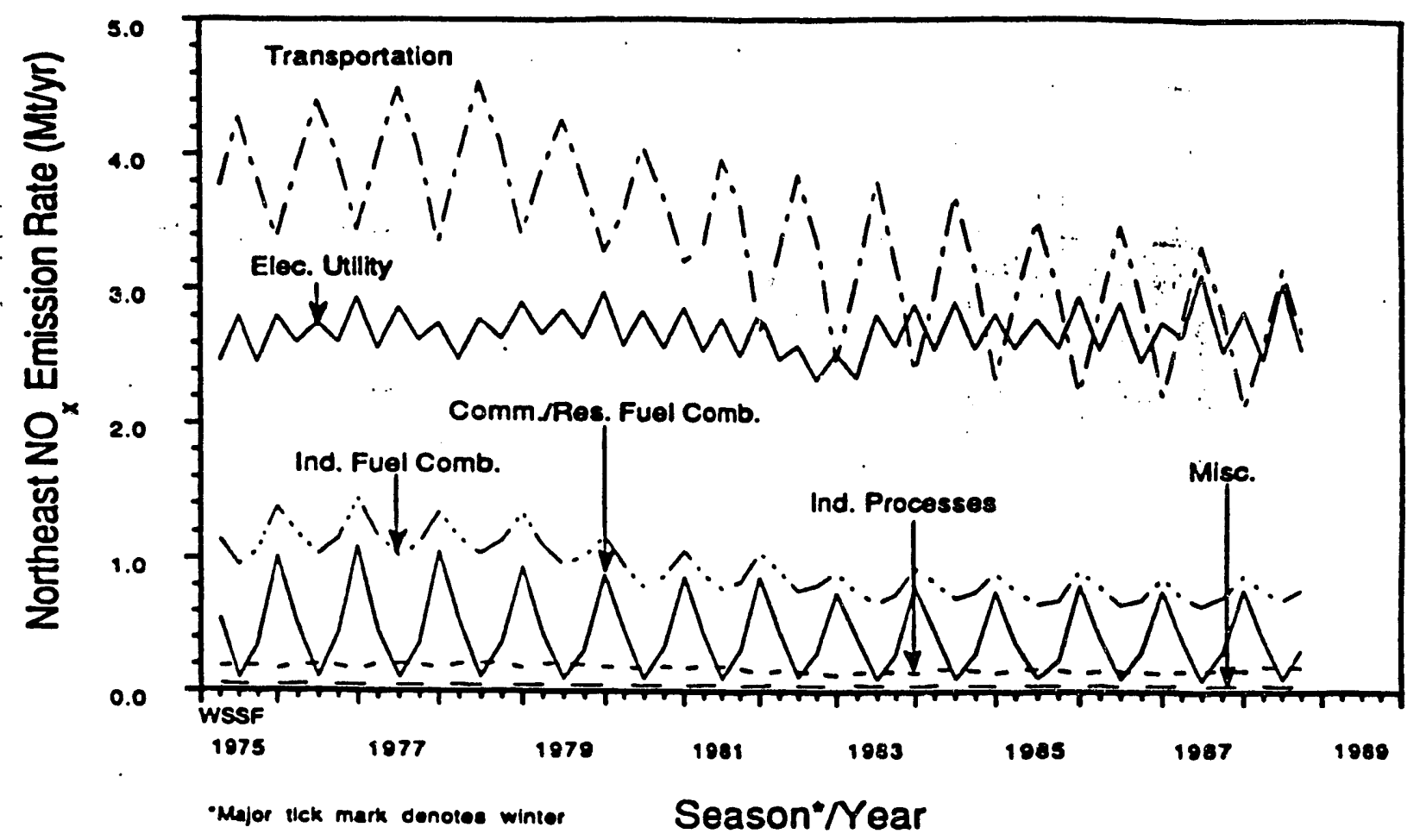

Northeast Sectoral NOx Emission Tirends Showing Seasonal Variations, 1975-1988

(b)

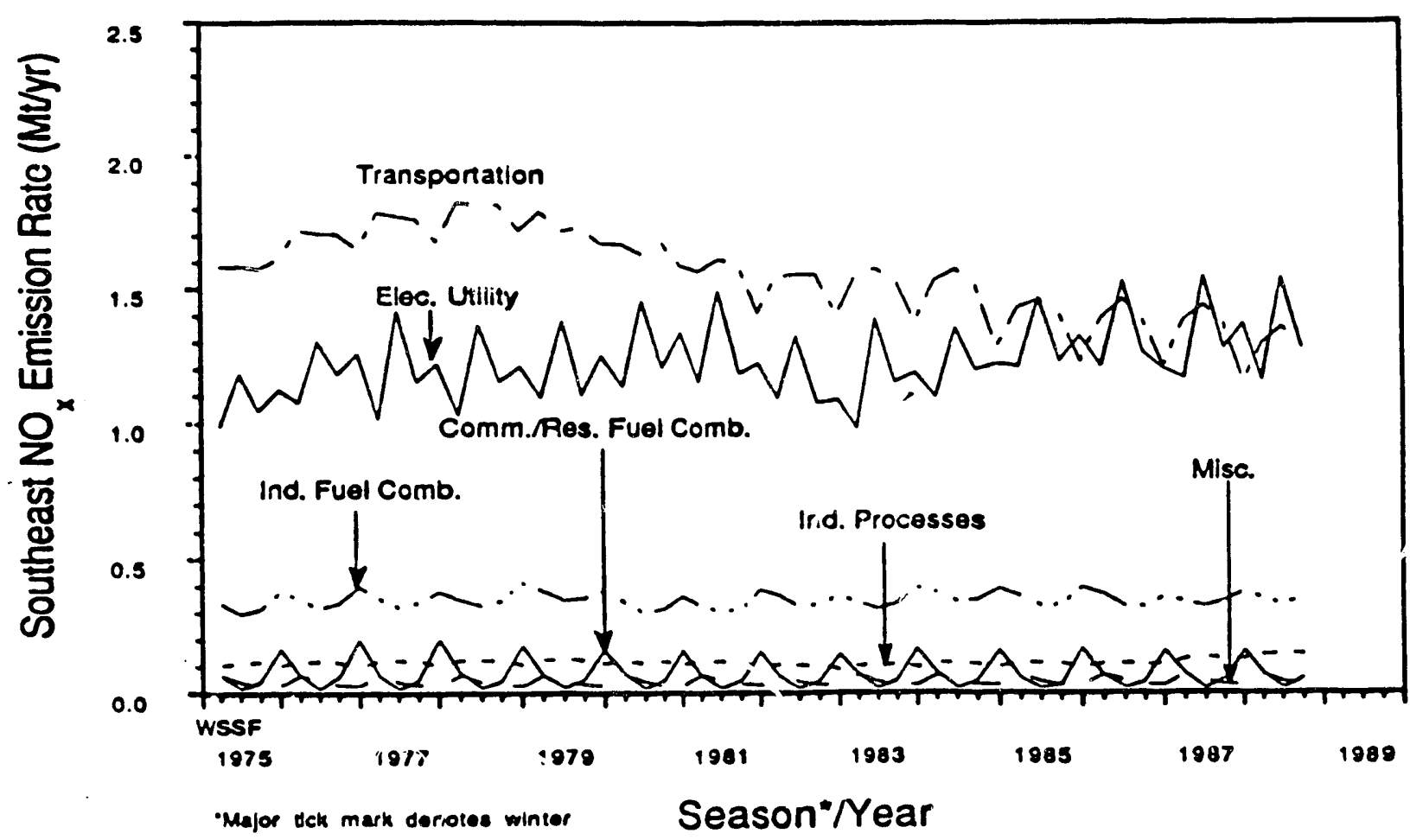

Southeast Seitoral NOx Emissions Trends Showing Seasonal Variations, 1975-1988

Fig. 24 


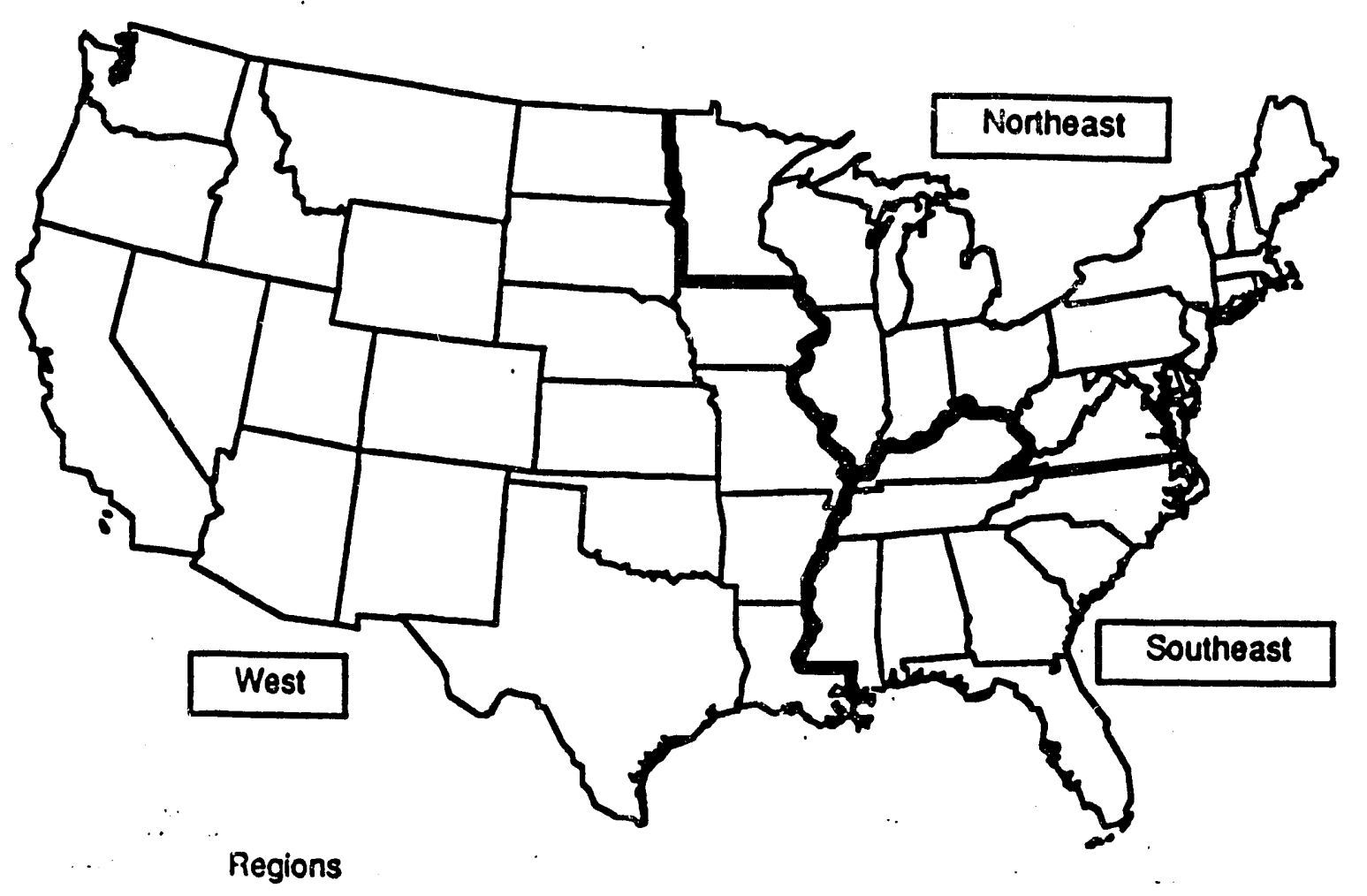

1

Fig. 25 


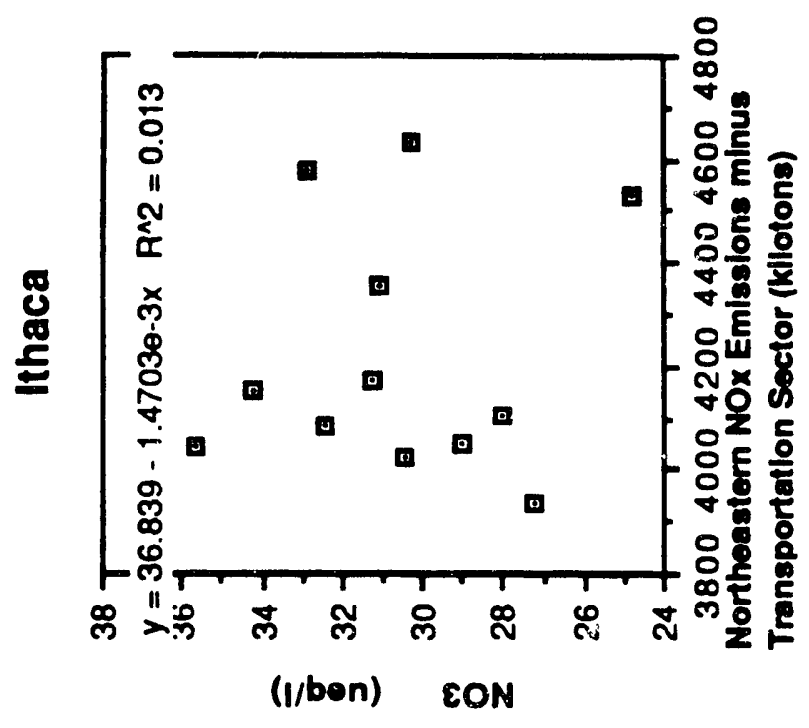

임

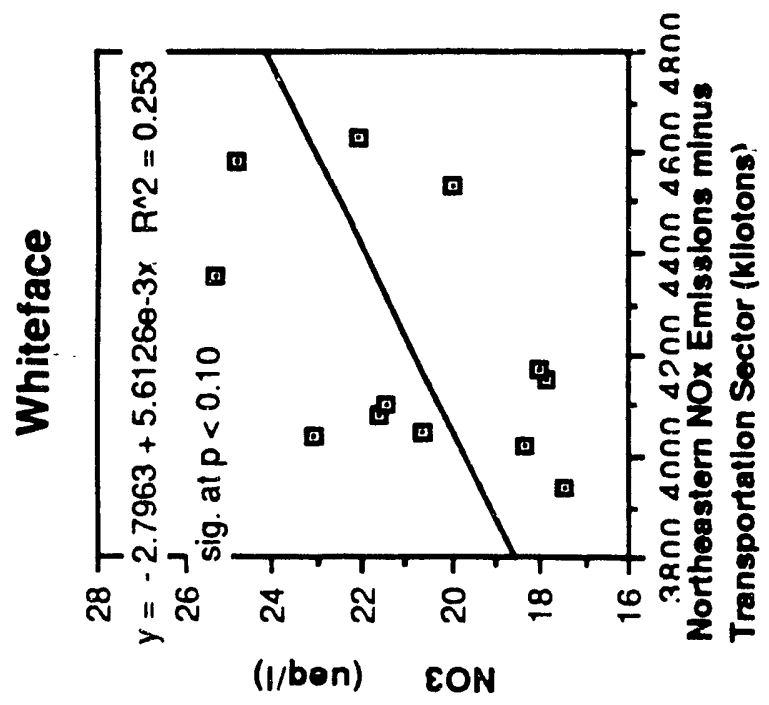

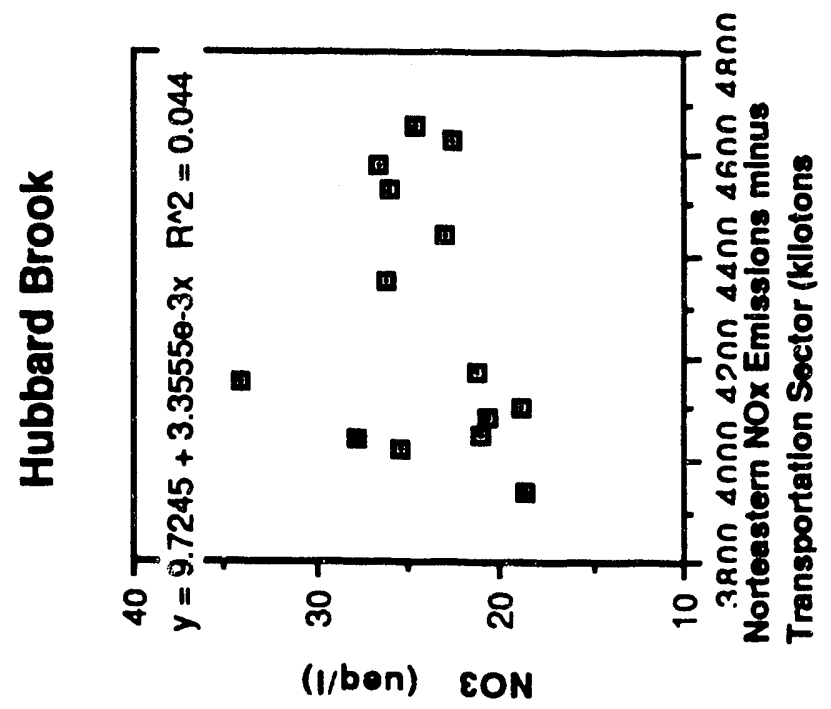
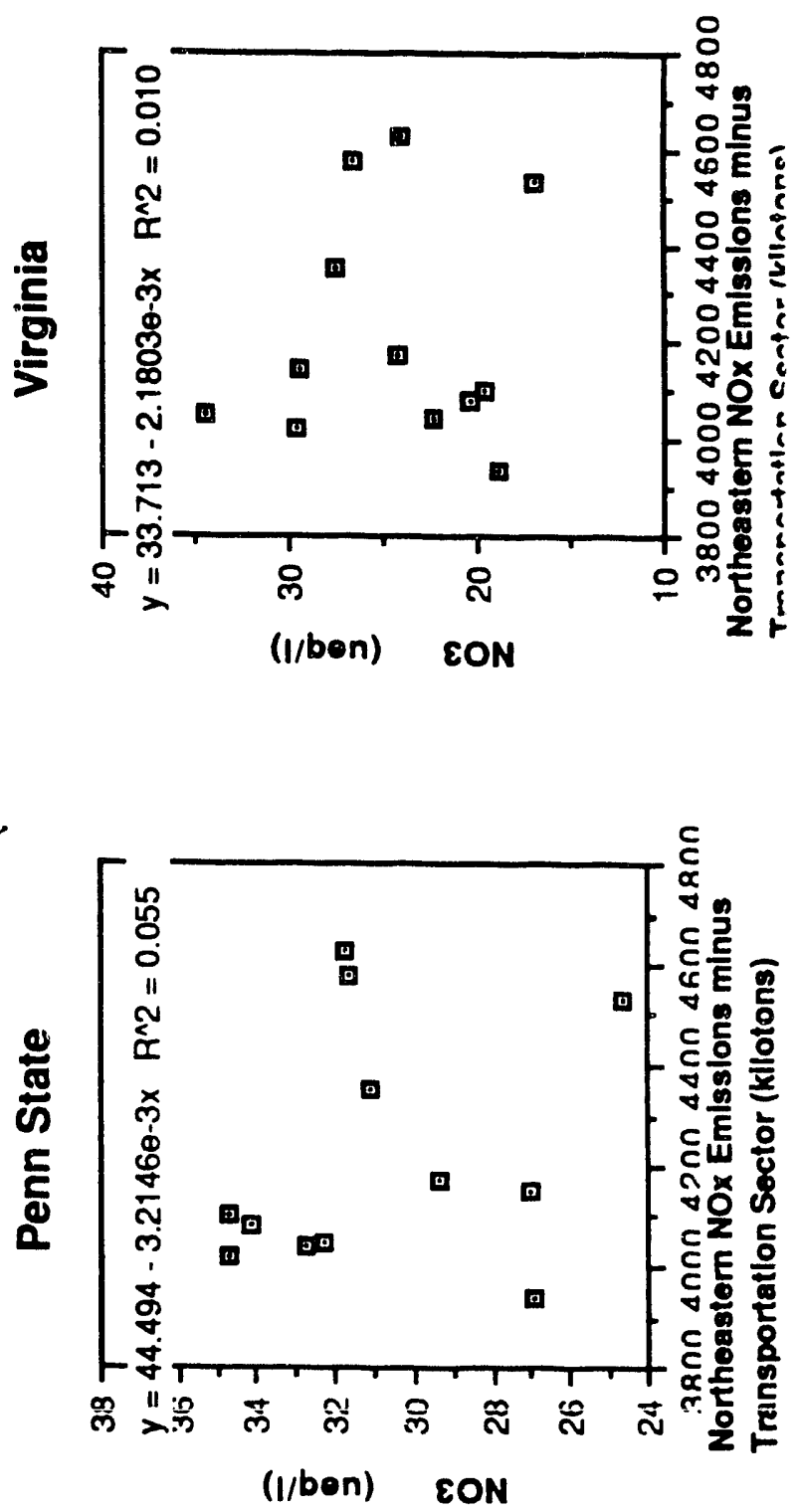


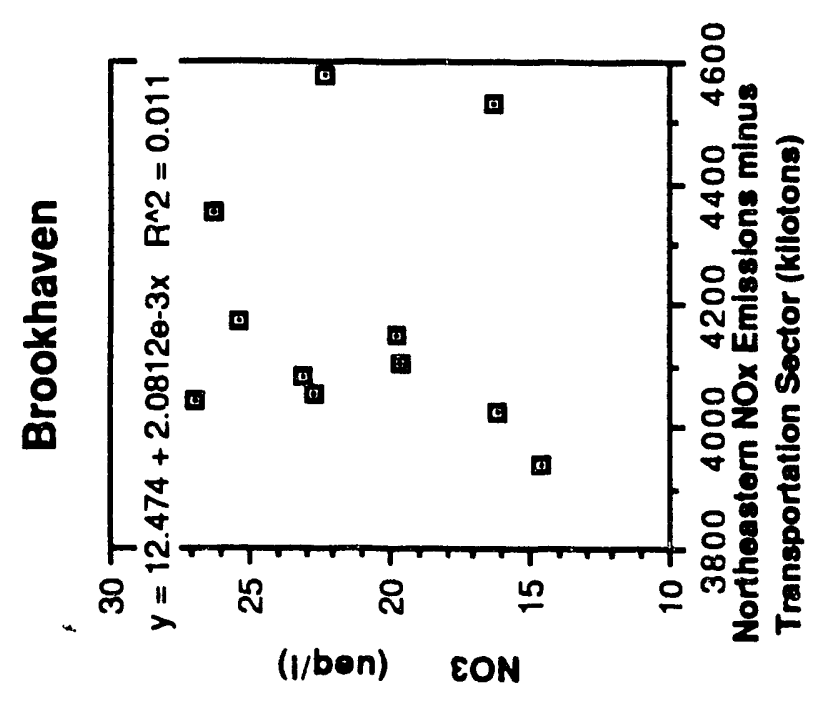

촐

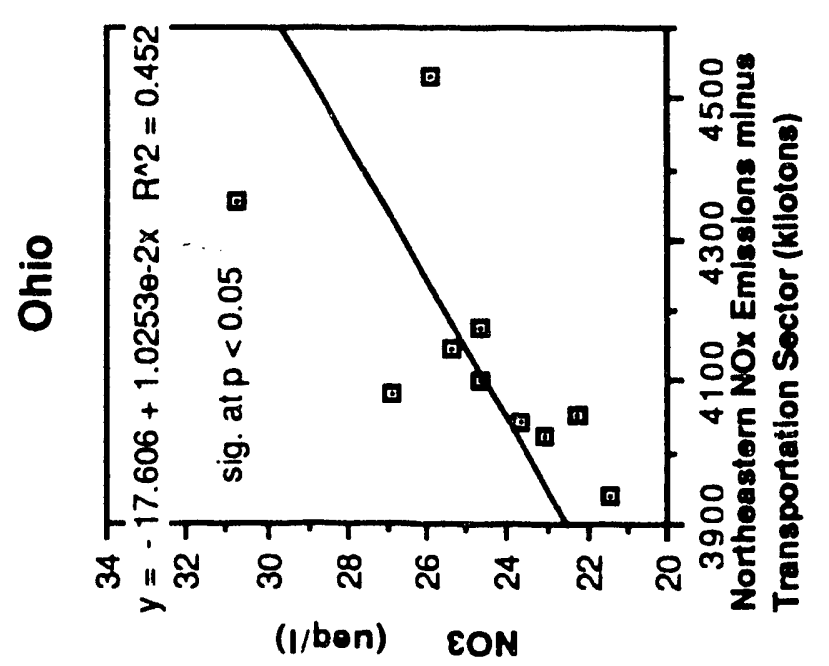

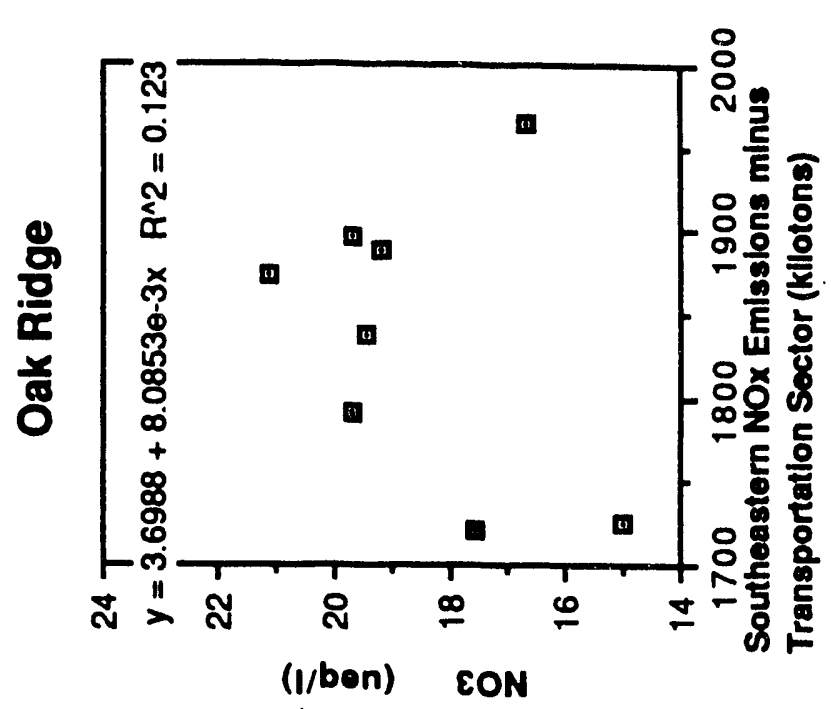
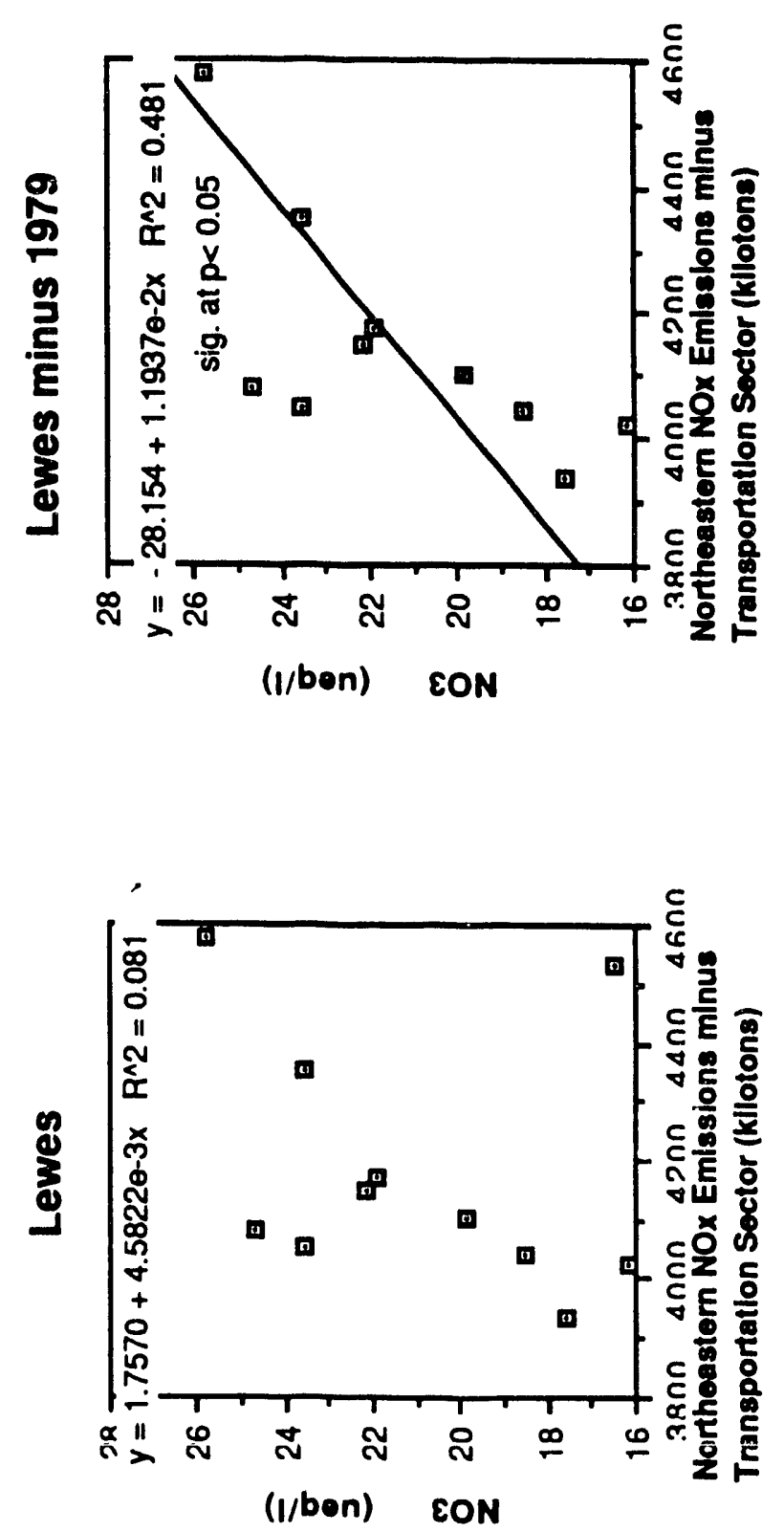


\section{APPENDIX A}

\section{BIBLIOGRAPHY OF MAP3S RELATED PUBLICATIONS FOR THE ITHACA SITE}

Butler, T. J. (1988). Composition of particles dry deposited to an inert surface at Ithaca, N. Y. Atmospheric Environment 22(5):895-899.

Butler, T. J. (1991). The impact of changing regional emissions on procipitation chemistry in the eastern United States. Atmospheric Environment 25A (2):305-315.

Butler, T. J. , C. V. Cogbill and G. E. Likens. (1984). Effect of Climatology on Precipitation Acidity. Bull. Am. Met. Soc. 65:639640.

Cogbill, C. V. , G. E. Likens and T. J. Butler. (1984). Uncertainties in historical aspects of acid precipitation: getting it straight. Atmospheric Environment 18: 2261-2268.

Galloway, J. N., G. E. Likens and M. E. Hawley. (1984). Acid precipitation: natural versus anthropogenic components. Science 226: $829-831$.

Galloway, J. N., and G. E. Likens. (1986). The composition of precipitation in remote areas of the world. J. Atmos. Environ. and Acid Rain (China) 2: 34-39.

Galloway, J. N., Zhao Dianwu, Xiong Jiling and G. E. Likens. (1987). Acid rain: China, United States, and a remote, area. Science 236:1559-1562.

Hedin, L. O. (1989). Biogeochemical studies of the Hubbard Brook Ecosystem: carbon cycling in streams and acidic inputs in precipitation. Ph.D. Thesis, Yale University. 180 pp.

Hedin, L. O., G. E. Likens, F. H. Bormann. (1987) Decrease in precipitation acidity resulting from decreased $\mathrm{SO}_{4}=$ concentration. Nature 325:244-246. 
Hedin, L. O., L. Granat, G. E. Likens, anci H. Rodhe. (1990). Strong similarities in seasonal concentration ratios of $\mathrm{SO} 4=$, NO3-, and $\mathrm{NH} 4+$ in precipitation between Sweden and northeastern U. S. Tellus 42B:454-462.

Likens, G. E. (1984). Acid rain: The smokestack is the "smoking gun." Garden 8(4):12-18.

Likens, G. E. (1986). Acid rain: causes, consequences and correctives. J. Atmos. Environ. and Acid Rain 1(1):33-40 (in Chinese, translated by Zhao Dianwu to English summary).

Likens, G. E. (1987). Acid rain and its influence on sedimentwater exchange in lakes and streams. Abstract for the Fourth International Symposium on the Interactions Between Sediments and Water, Melbourne, Australia. February 1986.

Likens, G. E. (1988). Chemical wastes in our atmosphere -- an ecological crisis. Industrial Crisis Quarterly 1(4):13-33.

Likens, G. E. (1988). Information needs--aquatic. pp. 101-119. In: J. C. White (ed.). Acid Rain: The Relationship Between Sources and Receptors. Elsevier Science Publishing Co., Inc.

Likens, G. E. (1989). Acid rain and its effects on sediments in lakes and streams. Hydrobiologia 176/177:331-348.

Likens, G. E. (1989). Some aspects of air pollution on terrestrial ecosystems and prospects for the future. Ambio 18: 172-178.

Likens, G. E. (1989). Evaluating stresses on temperate forest ecosystems. In: G. B. Marini-Bettolo (ed.). Study Week on "A Modern Approach to the Protection of the Envirunment." Pontifical Academy of Sciences, Nov. 1987. Pontificiae Academiae Scientiavm Scripta Varia 75.

Likens, G. E. (1991). Environmental problems in the 1990's: an ecological perspective. In: Environmental Problems: Global and Regional Concerns. Annual Meeting of Vermont Academy of Arts and Sciences, Burlington, VT. (In Press) 
Likens, G. E. (1991). Use and abuse of the ecosystem concept. Proc. First European Symp. on Terrestrial Ecosystems: Forests and Woodlands. Florence, Italy. May 1991. (In Press)

Likens, G. E., and T. J. Butler. (1981). Recent acidification of precipitation in North America. Atmospheric Environment 15:1103-1109.

Likens, G. E., R. F. Wright, J. N. Galloway, and T. J. Butler. (1979). Acid Rain. Scientific American 24:43-51.

Likens, G. E. L. O. Hedin, and T. J. Butler (1990). Some long-term precipitation chemistry patterns at the Hubbard Brook Experimental Forest: extremes and averages. Verh. Internat. Verein. Limnol. 24: 128-135

Weathers, K. C., G. E. Likens, F. H. Bormann, J. S. Eaton, W. B. Bowden, J. L. Anderson, D. A. Cass, J. N. Galloway, W. C. Keene, K. D. Kimball, P. Huth and D. Smiley. 1986. A regional acidic cloud/fog water event in the eastern United States. Nature 319:657-658.

Weathers, K. C., G. E. Likens, F. H. Bormann, S. H. Bicknell, B. T. Bormann, B. C. Daube, Jr., J. S. Eaton, J. N. Galloway, W. C. Kenne, K. D. Kimball, W. H. McDowell, T. G. Siccama, D. Smiley, and R. A. Tarrant. (1988). Cloud water chemistry from ten sites in North America. Environ. Sci. Tech. 22(8):1018-1026. 

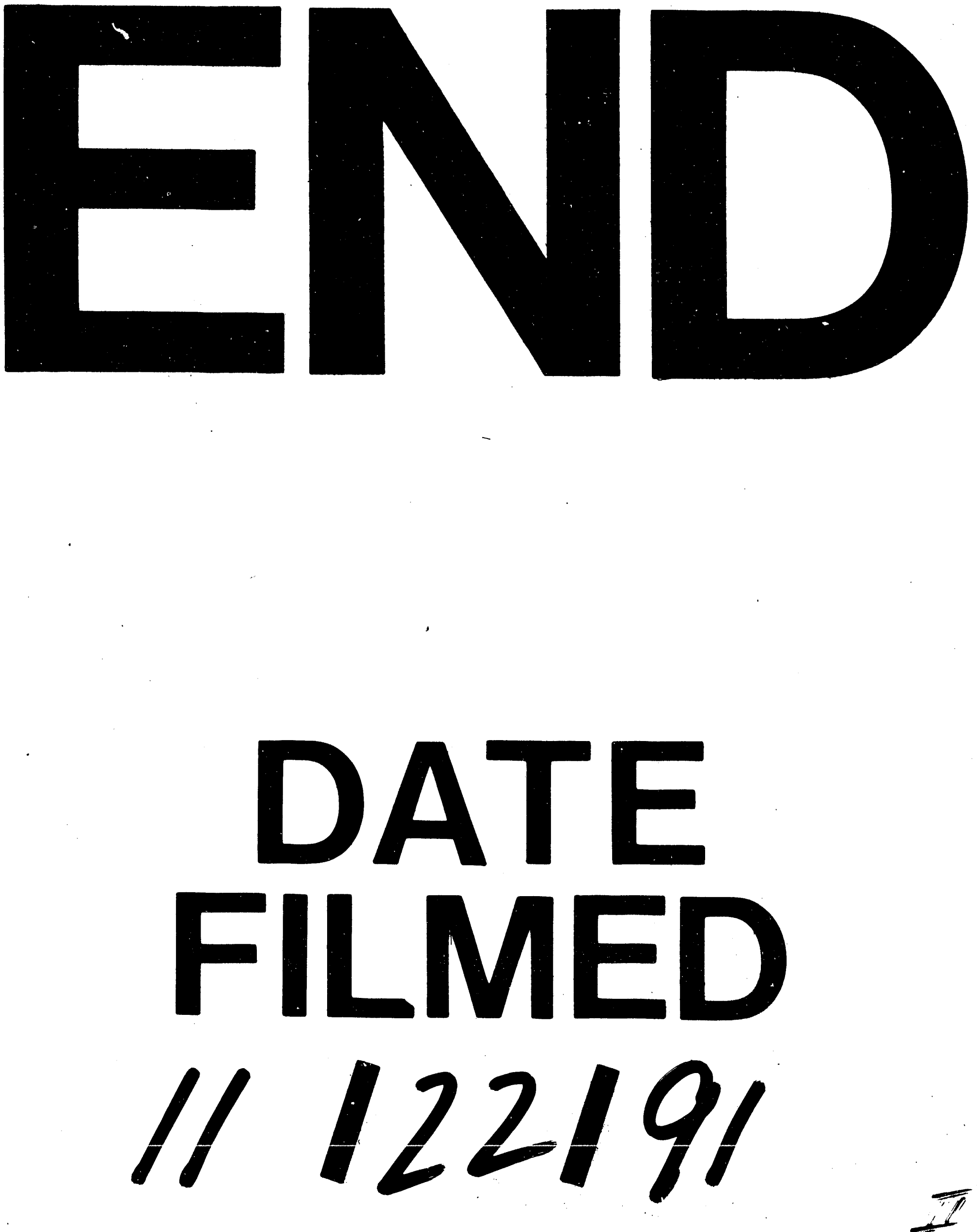

I 
